\title{
Racialized Preferences in Context: The Geography of White Opposition to Welfare
}

\author{
Nina M. Yancy \\ Doctoral Candidate in Politics \\ Department of Politics and International Relations \\ University of Oxford \\ nina.yancy@univ.ox.ac.uk \\ +44(0) 7472503244
}

\begin{abstract}
Research has shown that white Americans oppose welfare spending in part due to their racial prejudices. Yet, this conventional wisdom ignores the importance of local geography in determining whether whites are likely to view welfare in racialized terms. This article demonstrates that the effect of prejudice on whites' welfare preferences depends on the salience of welfare's racialized image in a given geographic context. I present a novel application of the racial threat hypothesis conceptualizing both prejudice and place as multidimensional-to argue that the racial geography of an area amplifies the effect of traditional racial stereotypes on welfare preferences, whereas economic geography amplifies the effect of symbolically racist attitudes. I test these propositions using geocoded data from the years following the 1996 US welfare policy reforms. My analysis reveals that racial attitudes are more predictive of welfare preferences not simply where the stigmas of welfare are salient due to a large black population or high poverty rate, but more specifically where residential segregation makes black or poor households more visible from the viewpoint of whites. These findings highlight the subjectivity of the white perspective, and call for more scholarship theorizing whites' agency in seeing racialized issues as threatening to white interests.
\end{abstract}

Keywords: Racial threat; welfare; racial attitudes; segregation

Address for correspondence: University College, High Street, Oxford, OX1 4BH, United Kingdom. 
Few themes have been more central to the work of black American scholars and authors than black (in)visibility, and the subjectivity of when and how blacks are perceived by whites (e.g. Du Bois 1903; Ellison 1952; Baldwin 1955; hooks 1992). To an extent, racial politics scholarship shares this focus. Scholars show how race is strategically rendered invisible, for example, in research on "colorblindness" as either a rhetorical strategy (Mendelberg 2001) or organizing principle for institutional orders (King and Smith 2005). Conversely, the capacity of race to be hyper-visible even when unmentioned features in research on the racialization of politics. By "racialization" (Omi and Winant 1986), scholars typically mean the process by which certain issues become associated with images and stereotypes of blacks (Gilens 1996; Hurwitz and Peffley 1997). As a result of this process, whites' orientations toward blacks, referred to as "racial attitudes," serve as powerful predictors of white opinion not only on explicitly racial issues, but also on issues implicitly associated with blacks (Kinder and Sanders 1996; Tesler 2012).

Despite engaging with the constructed nature of racial imagery, political science accounts lack a cogent theorization of whites' active role in drawing on this imagery to form political preferences. On the one hand, individual-level analyses posit racial attitudes as predictive of whites' policy preferences, but rarely consider the capacity of racial attitudes to either remain latent or respond depending on how whites view the world around them. On the other hand, contextual analyses assign importance to what whites see in their surroundings. Yet, the existing literature uncritically equates a black population with a "threat" to whites (Blalock 1967) while downplaying that whites construe blacks as threatening through the lens of racial prejudice.

This article offers a novel approach to theorizing how whites are likely to "see" racial politics, based on where they live and the racial prejudices they hold. I demonstrate that the salience - or rather, the visibility — of a racialized issue in whites' local surroundings is a 
crucial predictor of the likelihood that whites draw on their racial attitudes when expressing policy preferences.

I make this argument in regard to welfare spending, a quintessential example of a racialized policy due to its strong associations with negative racial stereotypes (Gilens 1995, 1999). These associations may be supported in part by the burden of poverty among blacks, but they primarily reflect how welfare has been politicized: as a threat to the way of life of "hardworking Americans"- often assumed to be white - by fueling lifestyles of dependence among the black, urban poor (Soss and Schram 2007).

I demonstrate that racial attitudes are more predictive of welfare preferences in metropolitan areas where welfare's racialized image is more visible, due to either a large black population share or a high poverty rate. More specifically, whether racial or economic geography is relevant depends on the racial attitude in question. The effect of traditional prejudice on welfare preferences is amplified when a proximate black population raises the salience of race, whereas the effect of symbolic racism is heightened in high poverty settings. In repeating this analysis using measures of racial and income segregation, I further show that the visibility of black or low-income households is a product of not just their presence, but also their patterning across a metropolitan area.

These findings shine new light on the dynamics of racial threat as a product of whites' individual-level prejudices as well as their subjective perceptions of the world. By positing whites as active perceivers of their surroundings, my analysis also allows for populations seen as threatening by some whites to be interpreted differently by others. The salience of race or poverty may thus provoke greater support for welfare spending among racially tolerant whites - a possibility ignored by conventional applications of the threat hypothesis. Taken together, my findings reveal that welfare preferences are more polarized by racial attitudes in settings where the stigmas of welfare are most visible to whites. 
I offer evidence for these claims using geocoded data from the General Social Survey (GSS) following the 1996 welfare reforms. Additional support for my findings comes from a replication of the analysis using contemporaneous data from the American National Election Study (ANES). The next section introduces welfare as a policy issue whose racialized image drew heavily on imagery of the black, urban poor. I then review existing scholarship on the relationships between racial attitudes, local contexts, and policy preferences, before discussing the theory informing my expectation that racial and economic geography will affect the relevance of racial attitudes to white opinions on welfare. The remainder of the article presents my methods and models; tests the robustness of the analysis against potential threats to inference; and discusses the implications of this research for scholarship on racialized policy preferences and racial politics more generally.

\section{Race, Poverty, and the Symbolic Politics of Welfare}

This article argues that whites' welfare preferences are more likely to be racialized-or predicted by whites' racial attitudes - in geographic settings where either race or poverty is more visible. Foundational to this claim is welfare's reputation, particularly among whites, as a benefit to the black, urban poor.

Although there is a long American tradition of doubting the deservingness of the poor (M. Katz 1989), the politicization of the term "welfare" in regard to the supposedly undeserving black poor dates to the 1960s. As told by Gilens (1999), the post-war boom was fading; poverty was reemerging as a national concern; and black poverty was drawing new attention due to civil unrest in cities across the country, as well as an emphasis by Civil Rights leaders on economic empowerment.

The disproportionate burden of poverty among blacks was hardly a phenomenon of the 60s. What was new was the disproportionate number of blacks receiving Aid to Families with 
Dependent Children (AFDC), many states having excluded blacks from the program in its early years. Because states had slowly dropped exclusions, over $40 \%$ of AFDC beneficiaries were black as of the 60s (Turner 1993; see also Fox 2012). The racial composition of welfare recipients was only a precondition, however, for a much more sudden shift Gilens (1999) identifies between 1965 and 1967, when national media outlets drastically increased the representation of blacks in news coverage of poverty. Racial attitudes and welfare preferences, which had previously been uncorrelated, became closely related after 1965 (Kellstedt 2003). Similarly, the term "welfare" became code for cash and in-kind transfer programs (i.e. AFDC and Food Stamps) believed to benefit blacks at the cost of whites (Gilens 1996; Bobo and Kluegel 1993).

While the share of black welfare recipients began to decline after 1969, an increase in dense pockets of black poverty between 1970 and 1990 only exacerbated welfare's associations with both race and the geography of the inner city (Jargowsky 1996; Wilson 1987). These associations were further entrenched by intellectual and political debates at the time: economic devastation in black communities was proclaimed to be the product of a “culture of poverty" at best, or individuals' moral failures at worst (see Massey and Sampson 2009 , for a review). Welfare became one of several race-coded issues that drove racially resentful whites to the Republican Party (Carmines and Stimson 1989; Edsall and Edsall 1991), but both parties used tropes such as the "welfare queen" as shorthand for black, single mothers with a "pathological" dependence on welfare (Hancock 2004). The replacement of AFDC with Temporary Assistance for Needy Families (TANF) in 1996 was meant to deracialize welfare, but stereotypes of black beneficiaries showed little change in the years after reform (Soss and Schram 2007).

This history is important to the present study for two reasons. First, it introduces the visual stigmas that featured in the racialization of welfare. Images of poor blacks, and the blighted 
neighborhoods they inhabited, were central to welfare's construal as a threat to hardworking (and implicitly white) Americans. This reputation not only led many Americans to drastically overestimate the scale of welfare spending and the proportion of beneficiaries who were black (Hacker 2004). It also framed welfare as an instance of racial group competitionexplaining why even whites with little personal interest in the matter might nonetheless oppose welfare spending in defense of whites' collective interests (Blumer 1958; Bobo 1983).

Second, welfare was politicized in relation to place as well as race, informing my expectation that whites' expression of racialized welfare preferences varies across metropolitan areas. In order to test this expectation, I synthesize individual-level and contextual models of whites' racial policy preferences - which are typically presented in isolation of one another. For example, a prominent individual-level analysis comes from Gilens $(1995,1996)$, who shows that opposition to welfare is greatest among whites who believe blacks lack a strong work ethic. Yet, Gilens ignores the possibility that whites' welfare preferences also reflect geographically clustered beliefs about the threat welfare poses to white interests.

A long line of research into the "racial threat" hypothesis (Key 1949; Blalock 1967) has suggested that, seeing blacks as a source of competition for political status, social wellbeing, and economic security, whites in proximity to a large black population will seek to protect white privilege and power. Subsequent work has identified a threat response in the form of white electoral support for anti-black or anti-redistributive candidates (Giles and Buckner 1993; but see also Voss 1996; Hersh and Nall 2016) as well as greater expressions of hostility toward blacks (Fossett and Kiecolt 1989; Giles 1977; Taylor 1998). Quillian $(1995,1996)$ has further illuminated the economic dimension of threat, arguing that prejudice is lessened when whites do not feel locked in a "zero-sum" competition over resources - a finding supported 
by research extending the threat hypothesis beyond whites' racial attitudes to their policy preferences. Contexts marked by low socioeconomic status, as well as by racial diversity, have been found to exacerbate white opposition to racial policies (Oliver and Mendelberg 2000; Branton and Jones 2005). My analysis builds on this approach by applying the logic of racial threat to whites' welfare policy preferences.

What is problematic about the racial threat hypothesis, however, is its reinforcement of the assumption that blacks are inherently threatening, rather than perceived as such from whites' subjective viewpoint. As a result, existing scholarship endorses the assumed neutrality of whites' perspective (Frankenberg 1993) and gives whites little responsibility in construing a threat. Therefore, while I follow the convention of operationalizing threat with a measure of black population share, I argue that threat is a consequence not of blacks' presence, but of whites' perceptions. This understanding underpins my analysis, which recognizes not only that individual-level prejudices are likely to affect how whites view their local geography, but also that welfare policy is likely to be viewed through a racial lens.

I thus diverge from Oliver and Mendelberg (2000), who find that context predicts policy preferences only within the geography in which a policy's benefits are distributed. These authors do not examine welfare preferences, but their argument comports with evidence that welfare provision is less generous in more diverse states, given that welfare is administered at the state level (Brown 1995; Hero and Tolbert 1996; Johnson 2001). However, to assume that whites are thinking specifically of their state's black population when asked about welfare would ignore that welfare was politicized as an urban issue, and that political behavior often reflects local (i.e. sub-state) concerns (Tobler 1970; Reeves and Gimpel 2012). I therefore analyze white welfare preferences as they vary across metropolitan areas - specifically, according to the salience of race and poverty in these local contexts. 
Similar reasoning informs my departure from Branton and Jones (2005). Although welfare is among the policy areas these authors analyze, they identify greater welfare opposition in settings with a high representation of multiple racial/ethnic groups. While valuable, this focus on racial heterogeneity is at odds with the extent to which welfare has been politicized in relation to black Americans more so than other minorities. I therefore conceptualize "racial diversity" in black-white terms.

Finally, I consider residential segregation, by both race and income, as a force likely to affect whites' perceptions of their surroundings. Scholars have given considerable attention to segregation's deeply harmful effects on the life outcomes of blacks (Massey and Denton 1993), as well as the consequences of lesser intergroup contact in segregated spaces (Allport 1954). In contrast to these experiential outcomes, there has been limited research into segregation's implications for a perceptual outcome such as sensing a threat to whites' interests (Pettigrew, Wagner, and Christ 2010). Because the segregation of blacks may either remove them from the public eye (Blalock 1967; Spitzer 1975) or increase the salience of high-density black areas (Stults and Baumer 2007), it is unclear whether racial segregation increases or decreases the expression of prejudicial views (for example, see the contradictory findings of Kinder and Mendelberg (1995) and Taylor (1998)). The effect of income segregation on attitudes is even more understudied: awareness of the poor may serve to inform people of the need for welfare support (Bamfield and Horton 2009), but it also may provoke more negative views of welfare recipients. This lack of clarity partly reflects the complexity of measuring the spatial distribution of households by either race or income. However, thanks to a range of indices measuring specific aspects of segregation, there is scope to build on the emerging literature considering segregation as a factor likely to shape the expression of racialized policy preferences (see also Baybeck 2006; Rocha and Espino 2009). 
In sum, scholars have poorly theorized whites' active perception of their surroundings in research on either the contextual dynamics of racial threat, or the individual-level expression of racialized policy preferences. I fill this gap by analyzing welfare preferences as they are shaped by both whites' racial attitudes and the contexts of racial diversity and poverty to which whites are exposed.

\section{A Contextual Model of Welfare Preferences}

I now outline a theory to test my conjecture that welfare preferences will be more racialized where the stigmas of welfare are more visible. I theorize, first, the responsiveness of racial attitudes to contextual cues; second, why different racial attitudes should be activated depending on the cue that is seen; and third, the potential for not only the presence but also the patterning of populations associated with welfare use to determine the salience of welfare's racialized image in a given context.

\section{The responsiveness of attitudes to context}

Research in political psychology supports the idea that local context will affect the salience of race or poverty, albeit looking beyond a geographic definition of context. Studies of racial priming, for example, offer compelling evidence that racial attitudes become more influential in political decision-making when these attitudes are made more accessible - or more quickly and easily retrieved - after exposure to a stimulus related to race (Mendelberg 2001; Valentino, Hutchings, and White 2002). The psychological process at play here is one akin to Zaller's (1992) model of attitudinal formation, which identifies political awareness as the crucial link determining whether individuals' preexisting values and beliefs are translated into their political preferences. Zaller argues that whether a predisposition informs someone's 
survey response depends on whether the respondent possesses the "contextual information" connecting this predisposition to the issue being surveyed.

Weber et al. (2014) extend this logic to the racial threat hypothesis by identifying a stronger relationship between racial stereotypes and policy preferences in racially diverse settings. These authors challenge the literature's conventional focus on how racial attitudes themselves vary across context, instead asking in what circumstances racial attitudes are likely to be consequential for politics (see also Velez and Lavine 2017). This shift is supported by insights from political economy that context (i.e. the structure of a welfare state) conditions the relevance of individual-level factors to social policy preferences (Gingrich and Ansell 2012). It also recognizes that racial attitudes themselves tend to be remarkably stable over time, whereas racial threat is a situational phenomenon (Enos 2016).

While Weber et al. offer a strong foundation for my approach, these authors operationalize racial context alone. I investigate whites' responses to racial and economic context on the understanding that either could indicate the salience of welfare's image. Because both blackness itself and concentrated, urban poverty are visual stigmas of welfare use, measures of the black population share or central city poverty rate should serve to indicate the salience of welfare's racialized image in a given setting. When that image is easily accessible, racial attitudes are more likely to be invoked in opposition to welfare spending, serving a psychological “need” (D. Katz 1960) to defend one’s way of life.

Although this argument implies that an individual would possess the same racial predispositions regardless of setting, I am cautious in posing racial attitudes as exogenous to context. Similarly, it is possible that whites' orientations toward blacks and public spending reflect regional or state culture. I discuss how I account for these considerations in the results section. Ultimately, it remains crucial to question the frequent assumption that the relationship between racial attitudes and welfare preferences is exogenous to context. 
Furthermore, I expect that measures of black population share or poverty rate will not independently predict a white individual's probability of expressing a particular welfare preference. The contextual measures should instead reveal their significance in relation to a white individual's existing racial attitudes, resulting in a heightened effect of racial attitudes when race or poverty is salient.

\section{Two dimensions of racial attitudes}

What attitudes would be amplified by the salience of race or poverty? I build on the work of scholars who argue that racial attitudes are multidimensional (Bobo 1983; Bobo and Kluegel 1993) and expect more than one formulation of prejudice to operate in defense of whites' interests. Moreover, if racial attitudes are akin to predispositions in Zaller's model, then the attitude that is brought to bear on welfare preferences should depend on the contextual information that is provided.

Accordingly, I operationalize two racial attitudes that should lead whites to construe either a large black population or a high poverty rate as a threat. The first follows from Gilens's finding that endorsing the traditional stereotype of blacks as lazy strongly predicts opposition to welfare. Because welfare is associated with blacks, a white individual who believes blacks are inherently lazy is likely to think of welfare as money spent on the undeserving poor.

The second racial attitude is a more nuanced expression of prejudice, alternatively called “symbolic racism,” (Kinder and Sears 1981) “modern racism” (McConahay 1986), or "racial resentment" (Kinder and Sanders 1996). I most closely follow the definition of symbolic racism, which uses the rhetoric of egalitarianism to normalize racial inequality, oppose "special favors" for blacks, and deny that discrimination rather than lack of effort explains why blacks remain disproportionately poor. Symbolically racist whites would oppose welfare spending not because they think all blacks are inherently lazy, but because "welfare" recalls 
images of the black poor who are believed to violate American values of self-reliance and discipline. This is a subtler view than a racial stereotype: it posits the prevalence of poverty among blacks, rather than race itself, as a sign of blacks' lesser commitment to hard work.

Both attitudes hold that blacks have a substandard work ethic, whether intrinsically or just generally. Yet, they are not identical. Consider how each attitude would respond to a middleincome black family. Whites who consider blacks inherently lazy would see this family as an exception to the rule. Whites who are symbolically racist, on the other hand, would see the middle-income black family as proof of their argument: if only more blacks would work harder, like this family has, then fewer black people would be poor.

Where this descriptive difference becomes a functional one is in the unique relationships we should expect between each racial attitude and local geography. The laziness stereotype explicitly posits race as an indication of someone's work ethic and consequential deservingness of poverty assistance. If skin color functions as a cue bringing the idea that blacks are lazy to the top of a white observer's mind, then the salience of black residents in a white individual's surroundings should predict the accessibility of this stereotype. Taking the percentage of blacks in a metropolitan area as a proxy for the salience of a black population, agreement with the laziness stereotype should be more predictive of opposition to welfare among whites who live in settings with a larger black presence.

On the other hand, symbolic racism uses the lower average economic status of blacks, rather than skin color itself, as an indicator of deservingness that explains racial inequality. Symbolic racism should thus be more accessible in settings where poverty, not race, is salient. In order to compare whites who live in settings with a similar black presence, I control for the black population share when positing a relationship between symbolic racism and local poverty rates. However, it should not be necessary that black poverty is salient in whites' surroundings for the salience of poverty in general to increase the accessibility of 
symbolic racism. Poverty is a structural condition of the American racial order, disproportionately affecting blacks thanks to a history of oppression, and often viewed by whites through a racial lens. Even the salience of non-black urban poverty should make the imagery of the black poor more accessible, and thus make whites more likely to draw on symbolic racism when evaluating welfare spending.

To test these conjectures, I corroborate the relationship between racial animus and opposition to welfare that has been identified in prior work, and then posit two parallel interactions between racial attitudes and context. My expectations are summarized in the following hypotheses:

- H1: Holding either traditionally or symbolically racist views will make a white individual more likely to oppose welfare.

- H2: Whites who hold traditionally racist views are more likely to oppose welfare in metropolitan areas where a larger share of the population is black.

- H3: Whites who hold symbolically racist views are more likely to oppose welfare in metropolitan areas where the poverty rate is higher.

Symbolic racism is not an uncontroversial concept. Its loudest critics argue that it does not measure racism at all but instead captures principled, conservative views about the appropriateness of government action to reduce racial inequality (Sniderman and Piazza 1993). The rejoinder of other scholars has been that principled conservatism only predicts conservative stances when race is involved (Schuman et al. 1997; Sidanius, Pratto, and Bobo 1996). I lack the scope to enter this debate. However, even if symbolic racism captures conservatism more than racism, identifying the amplified effect of this attitude on welfare preferences in settings where poverty is more salient would be valuable in revealing that attitudes about inequality between racial groups - whether reflective of animus or not - are responsive to economic context. 


\section{The role of segregation in shaping context}

The relationships proposed above assume that the salience of race or poverty in a given setting is determined by the presence of either a black population or a low-income population. Yet, patterns of residential segregation could also affect salience by making these populations more or less visible in the landscape of a metropolitan area. In a final step of analysis, I examine whether not only the presence of but also whites' exposure to racial diversity or poverty affects the relationship between racial attitudes and welfare preferences-even when comparing metropolitan areas with identical demographics.

I employ two indexes that measure segregation as the degree of exposure between groups in residential settings - whether white households sharing neighborhoods with black households, or nonpoor households sharing neighborhoods with poor households. For both measures, exposure is higher in metropolitan areas where neighborhoods are more mixed, and lower where neighborhoods are more homogeneous in their racial or economic makeup.

Crucial here is to consider how the dispersal of lower-income households as opposed to black households would affect the visibility of these populations. The visual stigmas of poverty are often environmental, stemming from signs of disorder related to disinvestment from poor communities (Sampson, Morenoff, and Earls 1999). Accordingly, low-income households are likely to be less visible when dispersed throughout mixed-income areas. Racial integration, on the other hand, does not make an individual black household less racially identifiable. While whites could be more aware of concentrated black populations than dispersed ones, blackness is a powerful visual stimulus when only a single face is present (Eberhardt et al. 2004). Particularly when comparing areas with similar black population shares, race would likely be more salient when a black household lives in a white household's neighborhood than when thinking of a concentrated black community across town. 
This logic informs my expectation that the effect of the laziness stereotype on welfare preferences will be amplified in settings where there is greater exposure of whites to blacks, while the effect of symbolic racism will be amplified where there is lesser exposure of the nonpoor to the poor. In both cases, I expect a stronger relationship between racial attitudes and welfare preferences in settings where either racial diversity or poverty is more visible based on residential segregation. Two final hypotheses summarize these expectations.

- H4: Whites who hold traditionally racist views are more likely to oppose welfare in metropolitan areas that are less segregated by race.

- H5: Whites who hold symbolically racist views are more likely to oppose welfare in metropolitan areas that are more segregated by income.

The above hypotheses prompt another consideration of whether racial attitudes are endogenous to contextual measures, particularly in the case of racial segregation. Racial attitudes likely have some influence on whites' tendency to prefer majority-white neighborhoods - a key factor explaining the persistence of racial segregation (Quillian 2002; Krysan and Bader 2007). Thus, it is possible that the level of racial segregation in a given metropolitan area is, in part, a product of the racial attitudes of the whites who live there. While keeping this potential endogeneity in mind, two further considerations suggest that exploring the relevance of racial segregation to whites' welfare preferences remains a valid approach. First, even in metropolitan areas where whites share neighborhoods with blacks, racial barriers often persist on a micro level (Logan and Parman 2017). This phenomenon reflects the difficulty of defining "segregation" in the first place. What it means for my analysis, however, is that the most racially prejudiced whites need not live in the most segregated metropolitan areas in order to avoid blacks in their most proximate residential surroundings. 
Second, I expect to identify a stronger effect of prejudice on welfare preferences in the least racially segregated areas. This finding should not simply reflect greater welfare opposition among the most prejudiced whites because these whites would, we assume, select into the most racially segregated areas. If anything, segregation may play a protective role, creating enclaves in which prejudiced whites avoid black neighbors and give little thought to racial diversity in their surroundings.

\section{Measuring Racial Attitudes and Local Contexts}

Public opinion data are drawn from the 2000 GSS. ${ }^{1}$ Locating my analysis in this year offers contextual data and segregation measures based on the 2000 decennial census, as well as proximity to the 1996 reforms, when the national salience of welfare would have made welfare opinions more sensitive to local contextual cues (Hopkins 2010). My dependent variable measures non-Hispanic white Americans' evaluations of welfare spending. I recode responses to a question asking whether the country spends "too much, too little, or about the right amount on welfare" to create a binary variable that captures opposition to existing spending levels ("too much"=1).

\section{Individual-level variables}

I operationalize the black laziness stereotype using whites' evaluations of blacks as either lazy or hardworking on a 1-7 scale. I adjust these values by each respondent's corresponding evaluation of whites' work ethic and rescale the variable between 0 and 10, with higher values reflecting placement of blacks closer to lazy $(M=5.31, S D=1.31)$.

I operationalize symbolic racism by conducting exploratory factor analysis on five variables from the 2000 GSS. I replicate the analysis of Tarman and Sears (2005), lending external validity to my measure, to extract a factor that captures symbolic racism as distinct 
from old-fashioned racism. ${ }^{2}$ The resulting symbolic racism factor most strongly captures agreement with three beliefs (factor loadings in parentheses). First, worse outcomes for blacks are due to a lack of motivation to succeed (0.49); second, blacks no longer face discrimination (0.47); and third, blacks should "work their way up" as other minority groups have (0.51). Full results of factor analysis are reported in the appendix. The symbolic racism variable is also scaled between 0 and 10 , with higher values reflecting higher levels of symbolic racism $(M=5.65, S D=2.48)$. Figure 1 illustrates the 0.47 correlation between the two racial attitude variables and supports a multidimensional approach to conceptualizing racial animus.

[Figure 1 about here]

Additional control variables include gender $($ male $=1)$, marital status (married=1), income (2000 dollars), and age and education (both measured in years). Dummy variables are used to measure identification as a Democrat, Independent, or Republican. ${ }^{3}$

\section{Contextual variables}

I measure racial and economic context at the level of the metropolitan statistical area (MSA). The politicization of welfare in regards to urban, black poverty motivates my focus on public opinion among non-rural whites. ${ }^{4}$ The higher density of MSAs also makes them settings where residents would be aware of visually identifiable communities associated with welfare.

No study assigning a role to context is immune from the modifiable areal unit problem (MAUP), or the propensity for the relationship between variables to depend on the scale and shape of the geographic container used for analysis (Fotheringham and Wong 1991). Measuring context at the metropolitan level mitigates this concern on two accounts. First, 
MSA boundaries should be large enough to capture indicators related to the visibility of welfare's stigmas even if people are sorted into neighborhoods by race or income. Although concerns about self-selection even at the neighborhood level may be overstated (Kaufmann and Harris 2015), it is costlier to move to a new metropolitan area than it is to select into a more favorable neighborhood within the same area. Second, people are likely to cross county lines in their daily activities and consume media that reports on issues in the wider area (Behr and Iyengar 1985). MSAs therefore are reasonable containers in which whites would be aware of the presence of black communities, as well as low-income ones. A final advantage of MSAs is that they are the units for which segregation is typically measured.

I thus isolate the 1,569 whites in the 2000 GSS sample who are located in 95 MSAs. I incorporate racial demographics using the percentage of black residents in each MSA as of the 2000 census, $\log$ transformed to account for the variable's right-skewed distribution. I incorporate economic context with a measure of the percentage of individuals living under the federal poverty line in the central city of an MSA, which aims to capture the salience of urban poverty. Although there is overlap between high-density black MSAs and high-poverty MSAs, the maps in Figure 2 reveal that there is considerable divergence, too. For example, a number of MSAs in the Southwest and West with large Hispanic populations have high poverty rates but small black populations. Cases such as these offer the opportunity to investigate how the local salience of poverty can activate symbolic racism even in the absence of a sizeable black population.

[Figure 2 about here]

In the online appendix, I repeat the analysis using county-level measures of context in order to check the robustness of the relationships I identify at the MSA level, heeding the warnings of the MAUP (Tam Cho and Baer 2011). Data on racial and income segregation are 
drawn from the US2010 Project (Logan 2011); these measures are discussed in greater detail below.

\section{Polarized Welfare Preferences in Settings of Threat}

I now test the proposition that racial attitudes have a greater effect on welfare preferences in settings with a larger black population share or higher poverty rate, depending on the racial attitude in question. I use binary logistic regression to estimate the probability that a white individual believes that too much is spent on welfare. All results are reported as odds ratios with standard errors clustered by MSA. ${ }^{5}$

I first corroborate the link between racial attitudes and welfare preferences documented in previous research. The first two models of Table 1 demonstrate that both racial attitudes are significant predictors $(\mathrm{p}<0.01)$ of welfare preferences, second only to partisanship in predictive power. Education is also a significant predictor of more positive evaluations of welfare in Model 1, consistent with studies finding that more educated individuals are less likely to hold traditional stereotypes-even if they remain defensive of white interests in other ways (Glaser 2001).

\section{[Table 1 about here]}

I next add measures of context to the analysis in order to test the two threat hypotheses. Models 3 through 5 of Table 1 include measures of black population share and poverty rate when controlling for whites' endorsement of the black laziness stereotype. As expected, neither contextual variable on its own is a significant predictor in Model 3. However, when controlling for an interaction between the laziness stereotype and black population share in Model 4, I find that racial geography conditions the effect of the belief that blacks are lazy on 
the probability of opposing welfare spending. In metropolitan areas with a negligible black presence, the black laziness stereotype is less predictive of opposition to welfare; but as the black population share increases, so does the predicted effect of endorsing a traditional stereotype.

To put this interaction in substantive terms, consider an unmarried white female in the dataset, positioned at the means of all individual variables, but at 7 out of 10 on the scale measuring the laziness stereotype. In an MSA where only 5\% of the population is black, her odds of saying too much is spent on welfare are $41.1 \%$. For an otherwise identical person living in a $25 \%$ black setting, these odds would increase to $50.8 \%$. To offer additional support for the argument that a larger black presence makes the laziness stereotype more accessible, I test whether the laziness stereotype responds similarly in high-poverty settings. The results reported in Model 5 indicate that no significant interaction exists between these two variables: holding the stereotype that blacks are lazy does not predict a greater likelihood of opposition to welfare in settings with higher poverty rates.

In Models 6 through 8 of Table 1, I repeat the above analysis but instead control for symbolic racism. I confirm in Model 6 that poverty rate does not independently influence welfare views; nor does it significantly interact with black population share in Model 7 . The interaction between poverty rate and symbolic racism posited in Model 8, however, is significant $(\mathrm{p}<0.05)$. The effect of symbolic racism on a white individual's welfare preferences is minimized for those individuals living in settings with low poverty rates. But, in higher-poverty settings, symbolic racism is more predictive of opposition to welfare.

Predicted probabilities again convey the substantive effects of the interaction term. Returning to the average single, white female in the dataset and placing her at 7 on the symbolic racism scale, this individual would have a $38.4 \%$ chance of saying too much is 
spent on welfare if she lived in an MSA with a $15 \%$ poverty rate in its central city. In a setting where $30 \%$ of the population was poor, this probability would increase to $59.3 \%$.

The findings reported so far identify unique responses of the laziness stereotype and symbolic racism to the local salience of either race or poverty. Taken together, the models further reveal that welfare preferences are more polarized by racial attitudes where welfare's racialized policy image is more accessible - whether due to the presence of a large black population or a high poverty rate. Figure 3 illustrates that, in low-density black or lowpoverty MSAs, racially prejudiced whites are no more likely than racially tolerant whites to oppose welfare spending. Yet, as either the black population or poverty rate increases, these probabilities diverge according to racial attitudes.

[Figure 3 about here]

The behavior of racially prejudiced whites is consistent with the conventional threat hypothesis. As the size of the subordinate group grows, or as resources seem scarcer in a given area, prejudiced whites are more likely to subscribe to the image of welfare as a threat to white interests and draw on their racial attitudes when forming policy preferences.

However, my findings also suggest that whites holding more positive feelings about blacks will find these orientations amplified when welfare's racialized image is more accessible. For whites who reject the laziness stereotype, the view that blacks are hardworking is likely to be more accessible in areas with larger black populations, making these whites more likely to support welfare spending. Correspondingly, whites with low levels of symbolic racism-who believe, for example, that discrimination helps sustain racial inequality - are predicted to be more supportive of welfare in higher-poverty settings.

It is possible that the behavior of the most racially tolerant whites in the sample reflects some degree of self-selection. Members of this category may be less averse to living near 
either racial diversity or poverty. At the same time, few whites in the sample hold expressly positive views of blacks. Only $6 \%$ of the sample rate blacks as more hardworking than whites, whereas $49 \%$ evaluate the races as equivalent. The symbolic racism scale is also weighted toward the racially prejudiced end. Therefore, the polarization I identify is likely driven by the amplification of prejudice more so than the amplification of tolerance.

Concerns about self-selection are minimal for the most racially prejudiced whites. Those with negative views of blacks are unlikely to seek out settings with larger black populations or higher poverty rates.

In sum, racial attitudes predispose whites to express a particular opinion on welfare, but whether whites connect these predispositions to their policy preferences depends on contextual information making the racialized dimensions of welfare salient. Moreover, the relevant contextual information depends on the attitude in question. Whites endorsing the black laziness stereotype are more likely to perceive a black population as an indicator of the threat welfare poses to white interests, whereas symbolically racist whites are more likely to perceive a poor population as an indication of threat.

\section{Investigating alternative explanations}

Two further investigations offer additional support for the findings presented thus far (results are reported in the online appendix). First, I have argued that it is because of welfare's politicization in regards to black, urban poverty that the presence of either a black or poor population will be relevant to whites' opinions on welfare spending. To test this assertion, I repeat the analysis with attitudes on "assistance to the poor" as the dependent variable. Neither contextual interaction holds when race-neutral phrasing is used. This result suggests the importance of the narrative and imagery associated with "welfare" in particular, as opposed to poverty assistance more generally. 
Second, I consider the validity of positing whites' racial attitudes as exogenous to context, despite some evidence that prejudice is exacerbated in more diverse settings (e.g. Quillian 1995; Taylor 1998). After estimating the effect of black population share on both racial attitude variables and finding significant but small effects, I conclude that these effects are not large enough to bias my analysis. I also verify that the differences I identify between MSAs are not the product of unobserved factors related to the culture or history of a state or region. When repeating the analysis when controlling for the region in which each MSA is located, as well as building multilevel models that nest MSAs within states, in both cases I find that the interactions between local context and racial attitudes remain significant.

\section{Segregation and the Visibility of Threat}

The above analysis used black population share and poverty rate as proxies for whites' awareness of racial diversity or poverty in their metropolitan areas. I now repeat the analysis using measures of segregation by race and income. Using segregation indices based on exposure offers another approach to operationalizing whites' awareness of contextual stimuli related to welfare, but with a more literal focus on the visibility of these stimuli from whites' point of view.

I operationalize racial segregation using the exposure index, which includes a measure of white-black "interaction" in residential settings (see Massey and Denton 1993). ${ }^{6}$ This variable reflects the proportion of black households with which the average white household in an MSA will share a neighborhood. Areas that are least segregated by race take on the highest values of the exposure index, reaching a maximum where the proportion of blacks in the average white household's neighborhood is equal to the total proportion of blacks in the MSA. The exposure index is therefore correlated with black population share while also adding a new layer of spatial information to my analysis. 
I operationalize income segregation using an index capturing the proportion of families living in poor neighborhoods, defined as census tracts with median incomes less than twothirds that of the larger metropolitan area (Bischoff and Reardon 2014). In a similar fashion to racial segregation and black population share above, this income segregation measure reflects underlying levels of poverty because settings with higher poverty rates tend to have higher proportions of poor neighborhoods. In order to match the logic of exposure of the nonpoor to the poor, I create an inverse version of the economic segregation index. This rescaled variable locates the areas that are least segregated by income at the highest values of the index, representing settings of greater exposure to the poor.

To incorporate these measures, I begin by adding racial segregation to the model controlling for the laziness stereotype. Racial segregation is not significant on its own but interacts with the laziness stereotype in Model 2 of Table 2. The significant interaction $(\mathrm{p}<0.01)$ indicates that greater exposure of white households to black households amplifies the effect of racial attitudes on welfare preferences.

Although the interaction in Model 2 resembles the relationship between the laziness stereotype and black population share, it reveals previously unrecognized differences between MSAs with similar racial makeups but different levels of segregation. For example, the areas surrounding Detroit, MI and Washington, DC had similar black population shares as of 2000: $23 \%$ and 27\% black, respectively. While Detroit's exposure score was 5.59, Washington's was more than twice that at 13.62. If an average white male in the dataset scored at 7 on the black laziness scale and lived in Detroit, his odds of believing too much is spent on welfare would be $49.5 \%$. If he instead lived in Washington, with a higher chance of sharing a neighborhood with a black household, those odds would rise to $57.4 \%$. These results are robust to controlling for the region or state in which an MSA is located.

\section{[Table 2 about here]}


In areas with small black population shares, it is unlikely a white household will share a neighborhood with a black household no matter how dispersed black households are. Measuring racial segregation as exposure therefore has the most to add to our understanding of the spatial dynamics of threat in urban areas with substantial black populations. Nevertheless, the logic of exposure is applicable across all MSAs: where a black population is more visible, based on the greater exposure of whites to blacks, traditional prejudice will have a greater effect on welfare preferences.

Turning to income segregation, I find that exposure of the nonpoor to poor is not itself predictive of welfare preferences, but it interacts with symbolic racism to condition the effect of this racial attitude on welfare preferences. However, the direction of the effect is opposite to that of racial segregation: Model 4 in Table 2 indicates that the effect of symbolic racism is weaker where there are more mixed income neighborhoods, or rather, where there is greater exposure of the nonpoor to the poor. Consider New York City and Atlanta, cities with poverty rates around $21 \%$ and $24 \%$, respectively, as of 2000 . Whereas the proportion of poor tracts in the greater New York area was 0.26 , it was 0.13 in the Atlanta area. For the white male described above, were he to score a 7 on the symbolic racism scale, his odds of saying too much is spent on welfare would be $59.2 \%$ in the New York area. These odds would fall to $45.0 \%$ if he lived in the less income-segregated Atlanta area.

[Figure 4 about here]

Racial and income segregation thus have starkly different effects on the probability that the welfare preferences expressed by whites in a given setting are influenced by racial attitudes. These counter-directional relationships are illustrated in Figure 4. While greater exposure of whites to blacks raises the salience of race and consequently amplifies the effect of traditional prejudice on welfare preferences, greater exposure of the nonpoor to the poor 
dampens the effect of symbolic racism, as poverty becomes less salient when poor households are dispersed throughout an MSA.

These findings not only support my argument that whites' racial attitudes are more accessible where welfare's racialized image is more visible. They also highlight the subjectivity of the operation of racial threat. Even across MSAs with identical demographics, patterns of segregation could make the stigmas of welfare more or less visible, and whites' welfare preferences more or less racialized as a result.

\section{Polarized Welfare Preferences in the ANES}

My analysis of the 2000 GSS has offered three main insights. First, the strength of the relationship between racial attitudes and welfare preferences is conditioned by local context. Second, whether racial or economic context is relevant depends on the attitude in questioneither the black laziness stereotype or symbolic racism. Third, we can theorize racial and economic contexts as indicative of whether welfare's racialized image is locally visible, due to either the presence of a black or poor population, or the distribution of these populations according to residential segregation.

An external test of the robustness of these results comes from the replication of my analysis using contemporaneous data from the 2000 ANES. I locate white ANES respondents in their congressional districts as of the 106th Congress. Because congressional districts are apportioned by population, they are more variable in size than MSAs; but, districts allow me to measure racial and economic demographics at a more local level than states. ${ }^{7}$ My variables are similar to those used in my analysis of the GSS. I construct an identical measure of the black laziness stereotype, scaled between 0 and $10(M=5.85, S D=1.21)$. I approximate symbolic racism with views on whether blacks should "work their way up" as other minority groups have, also scaled between 0 and $10(M=7.22, S D=2.91) .{ }^{8}$ Data on black population 
share and poverty rates at the congressional district level are drawn from the census. Districtlevel segregation measures reflect weighted averages of the racial and income segregation indices across the MSAs that are partially or fully encompassed by a congressional district.

[Table 3 about here]

Table 3 reports odds ratios from binary logistic regression, clustering standard errors by district. The previously identified interactions between the laziness stereotype and racial context (Model 1) and between symbolic racism and economic context (Model 3) are significant at the $90 \%$ confidence level. This borderline significant relationship between attitudes and context is strengthened $(\mathrm{p}=0.001)$ when examining the behavior of the laziness stereotype according to whites' likelihood of sharing a neighborhood with a black household (Model 2). The greater significance of the interaction of the laziness stereotype with racial segregation than with black population share may reflect the influence of gerrymandering, which can produce artificially low- or high-density black congressional districts whose populations do not reflect that of a larger area. However, the average level of segregation in either the various MSAs located within a large district, or in the larger urban area surrounding a small district, would be less sensitive to gerrymandering. Together, Models 1 and 2 add confidence to the argument that, in sub-state geographies where a black population is more visible, the traditional stereotype of blacks as lazy is more predictive of opposition to welfare than in settings where race is less salient.

The ANES offers less conclusive evidence in regards to the behavior of symbolic racism. Beyond the moderately significant interaction between symbolic racism and poverty rate in Model 3, Model 4 does not produce evidence for a significant relationship between symbolic racism and income segregation. However, the direction of the relationship matches my findings in the GSS. The greater variation in size of congressional districts than MSAs also 
likely plays a role in explaining the insignificance of income segregation in the ANES, as well as the reduced significance of poverty rate. Concentrated poverty could be viewed from considerably greater proximity or distance, depending on the district. Although further research is needed into the relationship between income segregation and whites' policy preferences, my findings in the ANES are broadly consistent with my GSS analysis.

\section{Discussion}

This article has demonstrated not only who is most likely to oppose welfare based on racial prejudice, but also where such prejudices are most likely to be relevant based on the visibility of welfare's racialized policy image. Whites who stereotype blacks as lazy are likely to express greater opposition to welfare spending in general, but this probability increases in settings where a large black population raises the salience of race. Symbolically racist whites, on the other hand, become increasingly likely to oppose welfare in settings where high poverty increases the accessibility of beliefs about why blacks are disproportionately poor.

These findings challenge the common implication in the literature that a proximate black population poses a threat to whites. By instead theorizing whites as the perceivers of a threat, I reveal specific relationships between different racial attitudes and elements of context, as well as the amplification of both negative and positive orientations toward blacks.

A further contribution of the article comes from my analysis of segregation.

Operationalizing context with measures of segregation reveals the capacity for demographics associated with welfare to be more or less visible depending on their distribution throughout an MSA. Accordingly, welfare preferences are more likely to be racialized in a setting where a black or poor population is more visible, even if the underlying size of either population is identical to that in another MSA with different patterns of segregation. This finding 
highlights that the perception of a threat is influenced not only by racial attitudes, but also by whites' subjective interpretations of the worlds in which they live (Lippmann 1922; Wong et al. 2012).

The analysis presented here has two larger implications for racial politics. First, my analysis questions the reliability of racial attitudes as predictors of policy preferences. Racial attitudes are less reflective of whether someone is uniformly "racist" than indicative of how a white individual will evaluate a political issue when its racialized dimensions are salient. This interpretation should not minimize whites' agency in holding and deploying racially prejudicial views, but rather should serve as a reminder that prejudice may appear irrelevant to politics in some circumstances only to be incited in others.

Second, my analysis of the GSS suggests that the dispersal of lower-income families throughout more affluent neighborhoods would reduce the visibility of poverty as a contextual stimulus related to a racialized understanding of welfare. Although the ANES offers limited support for this conclusion, it comports with the imperative of reducing income segregation in order to improve the life outcomes of the poor. In the case of racial segregation, on the other hand, my analysis indicates that the dispersal of black families throughout white neighborhoods would not lower the salience of race as a factor influencing the expression of welfare preferences. This finding in no way questions the importance of fighting racial segregation and its harmful effects on black communities. However, it should serve as a warning against equating residential proximity with positive interracial contact (Laurence 2014, see also; Enos 2016), and more broadly against advocating for racial integration as an end in itself, rather than a strategy to ameliorate racial inequality (Pattillo 2009).

More research is needed to understand how racial and income segregation contextualize whites' racial policy preferences. Future work should also extend my analysis of welfare 
preferences following the 1996 reform bill to other racialized policy issues in other periods. Finally, research should move toward considering how the race and class of a black population intersect to influence white attitudes. My analysis suggests that symbolically racist whites react negatively to the salience of poverty, but not necessarily to the salience of race, raising the question of how whites respond to affluent black communities.

This final suggestion recalls Harris-Lacewell's (2003) critique of the tendency of scholarship on racial attitudes to center whites and ignore blacks, particularly downplaying the diversity of black thought and experience. Although my analysis keeps whites at the center, I do so in order to interrogate whites' responsibility as agents of prejudice, rather than victims of racial threat. Thus, this article makes a recommendation for scholarship on white racial attitudes that should complement Harris-Lacewell's. To understand the persistent influence of whites' prejudices in politics, we must critically theorize whites' agency and subjectivity in perceiving the world through a racialized lens; interpreting blacks as threatening; and drawing on racial prejudice when forming political preferences.

\section{Acknowledgements}

I would like to thank Desmond King, Ben Ansell, Ursula Hackett, Jane Gingrich, Sidney Milkis, Nora Wilkinson, Jacob Taylor, Alexandra Zeitz, David Adler, and Rachel Benoit for their constructive comments and criticisms. I also am grateful to seminar participants at the Rothermere American Institute and to the reviewers and editors at the JREP for their valuable feedback. Funding for this research was generously provided by the Department of Politics and International Relations at the University of Oxford. 


\section{Notes}

1. Some of the data used in this analysis are derived from Sensitive Data Files of the GSS, obtained under special contractual arrangements designed to protect the anonymity of respondents. These data are not available from the author. Persons interested in obtaining GSS Sensitive Data Files should contact the GSS at GSS@NORC.org.

2. The Kaiser-Meyer-Olkin measure of sampling adequacy for the variables included in the factor analysis is 0.66 , above the recommended value of 0.60 . Bartlett's test of sphericity was also significant $(\mathrm{p}=0.00)$ supporting a rejection of the null hypothesis that the variables are noncollinear and thus unsuitable for structure detection.

3. I do not simultaneously control for ideology in order to reduce the collinearity or endogeneity of using self-placement on a left-right scale to predict a dependent variable that likely informs ideological self-definition in the first place, as pointed out by Strolovitch (1998). There is a good chance that opposing government spending on anti-poverty programs leads someone to identify as conservative rather than vice versa.

4. "Non-rural" refers to all respondents living near an urban center with a population of at least 50,000. Where applicable, I use data for metropolitan divisions, the subcategories into which the 11 largest MSAs are divided.

5. Clustering standard errors allows for correlation between observations in the same MSA, increasing the size of the confidence intervals in each model and raising the bar for finding a significant effect of a predictor variable on welfare preferences. Hierarchical analysis of the data produces an intraclass correlation coefficient (ICC) of only 0.01 in a null model, short of the typical threshold of 0.10 that would call for multilevel modeling. The number of respondents per MSA also is small (9.5 on average), which further reduces the 
need for a multilevel model. Thus, the results of a multilevel logistic analysis nesting individuals in MSAs are almost identical to those reported in Table 1.

6. White-black interaction $(w X b)$ is calculated as $\Sigma\left[\left(w_{\mathrm{i}} / W\right) *\left(b_{\mathrm{i}} / t_{\mathrm{i}}\right)\right]$, where $w_{\mathrm{i}}, b_{\mathrm{i}}$, and $t_{\mathrm{i}}$ represent the white, black, and total population of each census tract $i$, and $W$ represents the white population of the MSA. The more commonly used component of the exposure index is $b X b$, reflecting the isolation of blacks from whites in order to study the deleterious effects of segregation on blacks. However, a measure of white exposure to blacks is more appropriate for capturing how segregation shapes whites' perceptions of their surroundings.

7. At the most extreme, congressional districts encompass a whole state. For greater comparability to the GSS, I remove ANES respondents who reside in rural areas (defined as living more than 50 miles from an urban center) as well as those who reside in "at large" districts, which represent entire states.

8. I use this variable for comparability to the GSS, given that the 2000 ANES does not contain the variables necessary to replicate my original factor analysis. The "work way up" question loaded strongly on the factor extracted from the GSS data and captures the core sentiment of symbolic racism. 


\section{References}

Allport, Gordon. 1954. The Nature of Prejudice. Cambridge, MA: Addison-Wesley.

Baldwin, James. 1955. "Stranger in the Village.” In Notes of a Native Son. Boston: Beacon Press.

Bamfield, Louise, and Tim Horton. 2009. Understanding Attitudes to Tackling Economic Inequality. Joseph Rowntree Foundation.

Baybeck, Brady. 2006. "Sorting Out the Competing Effects of Racial Context.” Journal of Politics 68 (2): 386-396.

Behr, Roy L., and Shanto Iyengar. 1985. “Television News, Real-World Cues, and Changes in the Public Agenda.” Public Opinion Quarterly 49 (1): 38-57.

Bischoff, Kendra, and Sean F. Reardon. 2014. "Residential Segregation by Income, 1970-2009.” In Diversity and Disparities: America Enters a New Century, 43. New York: The Russell Sage Foundation.

Blalock, Hubert M. 1967. Toward a Theory of Minority-Group Relations. New York; London: John Wiley \& Sons, Inc.

Blumer, Herbert. 1958. "Race Prejudice as a Sense of Group Position.” The Pacific Sociological Review 1 (1): 3-7.

Bobo, Lawrence. 1983. “Whites’ Opposition to Busing: Symbolic Racism or Realistic Group Conflict?” Journal of Personality and Social Psychology 45 (6): 1196-1210.

Bobo, Lawrence, and James R. Kluegel. 1993. “Opposition to Race-Targeting: Self-Interest, Stratification Ideology, or Racial Attitudes?” American Sociological Review 58 (4): 443. Branton, Regina P., and Bradford S. Jones. 2005. "Reexamining Racial Attitudes: The Conditional Relationship between Diversity and Socioeconomic Environment." American Journal of Political Science 49 (2): 359-372. 
Brown, Robert D. 1995. "Party Cleavages and Welfare Effort in the American States." American Political Science Review 89 (1): 23-33.

Carmines, Edward G., and James A. Stimson. 1989. Issue Evolution: Race and the Transformation of American Politics. Princeton: Princeton University Press.

Du Bois, W.E.B. 1903. The Souls of Black Folk. Chicago, IL: A.C. McClurg \& Co.

Eberhardt, Jennifer L., Phillip Atiba Goff, Valerie J. Purdie, and Paul G. Davies. 2004. "Seeing Black: Race, Crime, and Visual Processing." Journal of Personality and Social Psychology 87 (6): 876-893.

Edsall, Thomas Byrne, and Mary Edsall. 1991. Chain Reaction: The Impact of Rights, Race and Taxes on American Politics. New York: W.W. Norton \& Company.

Ellison, Ralph. 1952. Invisible Man. New York: Vintage Books.

Enos, Ryan D. 2016. "What the Demolition of Public Housing Teaches Us about the Impact of Racial Threat on Political Behavior.” American Journal of Political Science 60 (1): 123142.

Fossett, Mark A., and K. Jill Kiecolt. 1989. “The Relative Size of Minority Populations and White Racial Attitudes.” Social Science Quarterly 70 (4): 820-835.

Fotheringham, A. Stewart, and David W. S. Wong. 1991. "The Modifiable Areal Unit Problem in Multivariate Statistical Analysis.” Environment and Planning 23 (7): 1025-1044.

Fox, Cybelle. 2012. Three Worlds of Relief: Race, Immigration, and the American Welfare State from the Progressive Era to the New Deal. Princeton: Princeton University Press.

Frankenberg, Ruth. 1993. White Women, Race Matters: The Social Construction of Whiteness. Minneapolis: University of Minnesota Press.

Gilens, Martin. 1995. "Racial Attitudes and Opposition to Welfare.” Journal of Politics 57 (4): 994-1014.

-. 1996. “"Race Coding' and White Opposition to Welfare.” American Political Science Review 90 (3): 593-604. 
-. 1999. Why Americans Hate Welfare: Race, Media, and the Politics of Anti-Poverty Policy. Chicago: University of Chicago Press.

Giles, Micheal W. 1977. "Percent Black and Racial Hostility: An Old Assumption Reexamined." Social Science Quarterly 58 (3): 412-417.

Giles, Micheal W., and Melanie A. Buckner. 1993. "David Duke and Black Threat: An Old Hypothesis Revisited." Journal of Politics 55 (03): 702.

Gingrich, Jane, and Ben Ansell. 2012. "Preferences in Context: Micro Preferences, Macro Contexts, and the Demand for Social Policy." Comparative Political Studies 45 (12): 16241654.

Glaser, James M. 2001. “The Preference Puzzle: Educational Differences in Racial-Political Attitudes." Political Behavior 23 (4): 313-334.

Hacker, Jacob S. 2004. “After Welfare.” The New Republic, $11^{\text {th }}$ October 2004.

Hancock, Ange-Marie. 2004. The Politics of Disgust: The Public Identity of the Welfare Queen. New York: NYU Press.

Harris-Lacewell, Melissa V. 2003. "The Heart of the Politics of Race: Centering Black People in the Study of White Racial Attitudes.” Journal of Black Studies 34 (2): 222-249.

Hero, Rodney E., and Caroline J. Tolbert. 1996. “A Racial/Ethnic Diversity Interpretation of Politics and Policy in the States of the US.” American Journal of Political Science 40 (3): $851-871$.

Hersh, Eitan D., and Clayton Nall. 2016. “The Primacy of Race in the Geography of IncomeBased Voting: New Evidence from Public Voting Records.” American Journal of Political Science 60 (2): 289-303.

hooks, bell. 1992. Black Looks: Race and Representation. Boston: South End Press.

Hopkins, Daniel J. 2010. “Politicized Places: Explaining Where and When Immigrants Provoke Local Opposition.” American Political Science Review 104 (1): 40-60. 
Hurwitz, Jon, and Mark Peffley. 1997. "Public Perceptions of Race and Crime: The Role of Racial Stereotypes.” American Journal of Political Science 41 (2): 375-401.

Jargowsky, Paul A. 1996. "Take the Money and Run: Economic Segregation in U.S.

Metropolitan Areas.” American Sociological Review 61 (6): 984-998.

Johnson, Martin. 2001. “The Impact of Social Diversity and Racial Attitudes on Social Welfare Policy." State Politics \& Policy Quarterly 1:27-49.

Katz, Daniel. 1960. "The Functional Approach to the Study of Attitudes." Public Opinion Quarterly 24 (2): 163-204.

Katz, Michael B. 1989. The Undeserving Poor. New York: Pantheon.

Kaufmann, Eric, and Gareth Harris. 2015. “'White Flight” or Positive Contact? Local Diversity and Attitudes to Immigration in Britain.” Comparative Political Studies 48 (12): 1563 1590.

Kellstedt, Paul M. 2003. The Mass Media and the Dynamics of American Racial Attitudes. Cambridge: Cambridge University Press.

Key, V.O. 1949. Southern Politics in State and Nation. New York: Vintage Books.

Kinder, Donald R., and Tali Mendelberg. 1995. "Cracks in American Apartheid: The Political Impact of Prejudice among Desegregated Whites." Journal of Politics 57 (02): 402.

Kinder, Donald R., and Lynn M. Sanders. 1996. Divided By Color: Racial Politics and Democratic Ideals. Chicago: University of Chicago Press.

Kinder, Donald R., and David O. Sears. 1981. "Prejudice and Politics: Symbolic Racism Versus Racial Threats to the Good Life." Journal of Personality and Social Psychology 40 (3): 414-431.

King, Desmond S., and Rogers M. Smith. 2005. "Political Racial Orders in American Development." American Political Science Review 99 (1): 75-92.

Krysan, Maria, and Michael Bader. 2007. "Perceiving the Metropolis: Seeing the City through a Prism of Race.” Social Forces 86 (2): 699-733. 
Laurence, James. 2014. "Reconciling the Contact and Threat Hypotheses: Does Ethnic Diversity Strengthen or Weaken Community Inter-Ethnic Relations?" Ethnic and Racial Studies 37 (8): 1328-1349.

Lippmann, Walter. 1922. Public Opinion. New York: Transaction Publishers.

Logan, John R. 2011. Separate and Unequal: The Neighborhood Gap for Blacks, Hispanics and Asians in Metropolitan America. Providence, RI: Brown University.

Logan, Trevon D., and John M. Parman. 2017. “The National Rise in Residential Segregation.” Journal of Economic History 77 (1): 127-170.

Massey, Douglas S., and Robert. J. Sampson. 2009. "Moynihan Redux: Legacies and Lessons.” The ANNALS of the American Academy of Political and Social Science 621 (1): 6-27.

Massey, Douglas, and Nancy Denton. 1993. American Apartheid. Cambridge, MA: Harvard University Press.

McConahay, John B. 1986. “Modern Racism, Ambivalence, and the Modern Racism Scale.” In Prejudice, Discrimination, and Racism, edited by John F. Dovidio and Samuel L. Gaertner, 91-126. New York: Academic Press.

Mendelberg, Tali. 2001. The Race Card: Campaign Strategy, Implicit Messages, and the Norm of Equality. Princeton: Princeton University Press.

Oliver, J. Eric, and Tali Mendelberg. 2000. "Reconsidering the Environmental Determinants of White Racial Attitudes.” American Journal of Political Science 44 (3): 574-589.

Omi, Michael, and Howard Winant. 1986. Racial Formation in the United States: From the 1960s to the 1980s. New York: Routledge \& Kegan Paul.

Pattillo, Mary. 2009. “Investing in Poor Black Neighborhoods 'As Is'.” In Public Housing and the Legacy of Segregation, edited by Margery Austin Turner, Susan J. Popkin, and Lynette Rawlings, 31-46. Washington, D.C.: The Urban Institute Press. 
Pettigrew, Thomas F., Ulrich Wagner, and Oliver Christ. 2010. "Population Ratios and Prejudice: Modelling Both Contact and Threat Effects." Journal of Ethnic and Migration Studies 36 (4): 635-650.

Quillian, Lincoln. 1995. "Prejudice as a Response to Perceived Group Threat: Population Composition and Anti-Immigrant and Racial Prejudice in Europe.” American Sociological Review 60 (4): 586.

-. 1996. "Group Threat and Regional Change in Attitudes Toward African-Americans." American Journal of Sociology 102 (3): 816.

-. 2002. "Why Is Black-White Residential Segregation So Persistent? Evidence on Three Theories from Migration Data.” Social Science Research 31 (2): 197-229.

Reeves, Andrew, and James G. Gimpel. 2012. "Ecologies of Unease: Geographic Context and National Economic Evaluations.” Political Behavior 34 (3): 507-534.

Rocha, Rene R., and Rodolfo Espino. 2009. "Racial Threat, Residential Segregation, and the Policy Attitudes of Anglos." Political Research Quarterly 62 (2): 415-426.

Sampson, Robert J., Jeffrey D. Morenoff, and Felton Earls. 1999. "Beyond Social Capital: Spatial Dynamics of Collective Efficacy for Children." American Sociological Review 64 (5): 633-660.

Schuman, Howard, Charlotte Steeh, Lawrence Bobo, and Maria Krysan. 1997. Racial Attitudes in America: Trends and Interpretations. Cambridge, MA: Harvard University Press. Sidanius, Jim, Felicia Pratto, and Lawrence Bobo. 1996. "Racism, Conservatism, Affirmative Action, and Intellectual Sophistication: A Matter of Principled Conservatism or Group Dominance?" Journal of Personality and Social Psychology 70 (3): 476-490.

Sniderman, Paul M., and Thomas Piazza. 1993. The Scar of Race. Cambridge, MA: Harvard University Press.

Soss, Joe, and Sanford F. Schram. 2007. “A Public Transformed? Welfare Reform as Policy Feedback." American Political Science Review 101 (1): 111-127. 
Spitzer, Steven. 1975. “Toward a Marxian Theory of Deviance.” Social Problems 22 (5): 638651.

Strolovitch, Dara Z. 1998. "Playing Favorites: Public Attitudes Toward Race- and GenderTargeted Anti-Discrimination Policy.” NWSA Journal 10 (3): 27-53.

Stults, Brian J., and Eric P. Baumer. 2007. "Racial Context and Police Force Size: Evaluating the Empirical Validity of the Minority Threat Perspective." American Journal of Sociology 113 (2): 507-546.

Tam Cho, W. K., and N. Baer. 2011. "Environmental Determinants of Racial Attitudes Redux: The Critical Decisions Related to Operationalizing Context." American Politics Research 39 (2): 414-436.

Tarman, Christopher, and David O. Sears. 2005. "The Conceptualization and Measurement of Symbolic Racism.” Journal of Politics 67 (3): 731-761.

Taylor, Marylee C. 1998. "How White Attitudes Vary with the Racial Composition of Local Populations: Numbers Count.” American Sociological Review 63 (4): 512.

Tesler, Michael. 2012. “The Spillover of Racialization into Health Care: How President Obama Polarized Public Opinion by Racial Attitudes and Race.” American Journal of Political Science 56 (3): 690-704.

Tobler, Waldo R. 1970. “A Computer Movie Simulating Urban Growth in the Detroit Region.” Economic Geography 46: 234-240.

Turner, Bobbie Green. 1993. Federal/State Aid to Dependent Children Program and its Benefits to Black Children in America, 1935-1985. New York: Garland Publishing.

Valentino, Nicholas A., Vincent L. Hutchings, and Ismail K. White. 2002. "Cues That Matter: How Political Ads Prime Racial Attitudes during Campaigns.” American Political Science Review 96 (1): 75-90.

Velez, Yamil Ricardo, and Howard Lavine. 2017. "Racial Diversity and the Dynamics of Authoritarianism.” Journal of Politics 79 (2): 519-533. 
Voss, D. Stephen. 1996. "Beyond Racial Threat: Failure of an Old Hypothesis in the New South.” Journal of Politics 58 (4): 1156.

Weber, Christopher R., Howard Lavine, Leonie Huddy, and Christopher M. Federico. 2014. "Placing Racial Stereotypes in Context: Desirability and the Politics of Racial Hostility." American Journal of Political Science 58 (1): 63-78.

Wilson, William Julius. 1987. The Truly Disadvantaged: The Inner City, the Underclass, and Public Policy. Chicago: University of Chicago Press.

Wong, Cara, Jake Bowers, Tarah Williams, and Katherine Drake Simmons. 2012. "Bringing the Person Back In: Boundaries, Perceptions, and the Measurement of Racial Context." Journal of Politics 74 (4): 1153-1170.

Zaller, John. 1992. The Nature and Origins of Mass Opinion. Cambridge: Cambridge University Press. 


\section{Tables}

Table 1: Racialized Welfare Preferences in Context

\begin{tabular}{|c|c|c|c|c|c|c|c|c|}
\hline \multirow[b]{2}{*}{ Opposition to Welfare } & $(1)$ & $(2)$ & (3) & (4) & $(5)$ & (6) & (7) & $(8)$ \\
\hline & \multicolumn{2}{|c|}{ Individual Level } & \multicolumn{3}{|c|}{ Laziness Stereotype \& Context } & \multicolumn{3}{|c|}{ Symbolic Racism \& Context } \\
\hline \multicolumn{9}{|l|}{$\underline{\text { Racial Attitudes }}$} \\
\hline$\overline{\text { Laziness Stereotype }}$ & $\begin{array}{c}1.263^{* * * *} \\
(0.096)\end{array}$ & & $\begin{array}{l}1.264 * * * \\
(0.097)\end{array}$ & $\begin{array}{c}0.897 \\
(0.150)\end{array}$ & $\begin{array}{c}0.983 \\
(0.234)\end{array}$ & & & \\
\hline Symbolic Racism & & $\begin{array}{c}1.225^{* * * *} \\
(0.073)\end{array}$ & & & & $\begin{array}{c}1.220 * * * \\
(0.073)\end{array}$ & $\begin{array}{c}1.105 \\
(0.104)\end{array}$ & $\begin{array}{c}0.792 \\
(0.138)\end{array}$ \\
\hline \multicolumn{9}{|l|}{ Contextual Variables } \\
\hline Percent Black (log) & & & $\begin{array}{c}0.982 \\
(0.084)\end{array}$ & $\begin{array}{c}0.436^{* * *} \\
(0.131)\end{array}$ & $\begin{array}{c}0.984 \\
(0.083)\end{array}$ & $\begin{array}{c}1.019 \\
(0.116)\end{array}$ & $\begin{array}{c}0.781 \\
(0.243)\end{array}$ & $\begin{array}{c}1.015 \\
(0.105)\end{array}$ \\
\hline Poverty Rate & & & $\begin{array}{c}1.001 \\
(0.020)\end{array}$ & $\begin{array}{c}1.001 \\
(0.020)\end{array}$ & $\begin{array}{c}0.931 \\
(0.057)\end{array}$ & $\begin{array}{c}1.025 \\
(0.023)\end{array}$ & $\begin{array}{c}1.026 \\
(0.023)\end{array}$ & $\begin{array}{l}0.891 * * \\
(0.047)\end{array}$ \\
\hline $\begin{array}{l}\text { Laziness Stereotype } \\
\times \text { Percent Black }(\log )\end{array}$ & & & & $\begin{array}{l}1.165^{* *} \\
(0.069)\end{array}$ & & & & \\
\hline $\begin{array}{l}\text { Laziness Stereotype } \\
\times \text { Poverty Rate }\end{array}$ & & & & & $\begin{array}{l}1.013 \\
(0.013)\end{array}$ & & & \\
\hline $\begin{array}{l}\text { Symbolic Racism } \\
\times \text { Percent Black (log) }\end{array}$ & & & & & & & $\begin{array}{c}1.046 \\
(0.045)\end{array}$ & \\
\hline $\begin{array}{l}\text { Symbolic Racism } \\
\times \text { Poverty Rate }\end{array}$ & & & & & & & & $\begin{array}{l}1.025^{* *} \\
(0.010)\end{array}$ \\
\hline \multicolumn{9}{|l|}{ Control Variables } \\
\hline Age & $\begin{array}{c}0.992 \\
(0.006)\end{array}$ & $\begin{array}{c}0.992 \\
(0.007)\end{array}$ & $\begin{array}{c}0.992 \\
(0.006)\end{array}$ & $\begin{array}{c}0.992 \\
(0.006)\end{array}$ & $\begin{array}{c}0.992 \\
(0.006)\end{array}$ & $\begin{array}{c}0.993 \\
(0.007)\end{array}$ & $\begin{array}{c}0.993 \\
(0.007)\end{array}$ & $\begin{array}{c}0.994 \\
(0.007)\end{array}$ \\
\hline Gender & $\begin{array}{c}1.282 \\
(0.246)\end{array}$ & $\begin{array}{l}1.230 \\
(0.292)\end{array}$ & $\begin{array}{l}1.278 \\
(0.245)\end{array}$ & $\begin{array}{c}1.276 \\
(0.245)\end{array}$ & $\begin{array}{c}1.275 \\
(0.245)\end{array}$ & $\begin{array}{c}1.226 \\
(0.290)\end{array}$ & $\begin{array}{c}1.225 \\
(0.290)\end{array}$ & $\begin{array}{c}1.239 \\
(0.299)\end{array}$ \\
\hline Marital Status & $\begin{array}{c}1.132 \\
(0.218)\end{array}$ & $\begin{array}{c}1.063 \\
(0.258)\end{array}$ & $\begin{array}{c}1.130 \\
(0.219)\end{array}$ & $\begin{array}{c}1.130 \\
(0.221)\end{array}$ & $\begin{array}{c}1.135 \\
(0.221)\end{array}$ & $\begin{array}{c}1.099 \\
(0.271)\end{array}$ & $\begin{array}{c}1.109 \\
(0.275)\end{array}$ & $\begin{array}{c}1.090 \\
(0.284)\end{array}$ \\
\hline Education (years) & $\begin{array}{l}0.930 * * \\
(0.033)\end{array}$ & $\begin{array}{c}0.950 \\
(0.043)\end{array}$ & $\begin{array}{l}0.930 * * \\
(0.033)\end{array}$ & $\begin{array}{l}0.933 * * \\
(0.032)\end{array}$ & $\begin{array}{l}0.931 * * \\
(0.034)\end{array}$ & $\begin{array}{c}0.949 \\
(0.044)\end{array}$ & $\begin{array}{c}0.954 \\
(0.044)\end{array}$ & $\begin{array}{c}0.954 \\
(0.046)\end{array}$ \\
\hline Income & $\begin{array}{c}1.000 \\
(0.000)\end{array}$ & $\begin{array}{c}1.000 \\
(0.000)\end{array}$ & $\begin{array}{c}1.000 \\
(0.000)\end{array}$ & $\begin{array}{c}1.000 \\
(0.000)\end{array}$ & $\begin{array}{c}1.000 \\
(0.000)\end{array}$ & $\begin{array}{c}1.000 \\
(0.000)\end{array}$ & $\begin{array}{c}1.000 \\
(0.000)\end{array}$ & $\begin{array}{c}1.000 \\
(0.000)\end{array}$ \\
\hline Independent & $\begin{array}{c}2.121^{* * *} \\
(0.569)\end{array}$ & $\begin{array}{l}2.233 * * \\
(0.725)\end{array}$ & $\begin{array}{c}2.126^{* * *} \\
(0.564)\end{array}$ & $\begin{array}{c}2.145^{* * *} * \\
(0.581)\end{array}$ & $\begin{array}{c}2.143^{* * *} \\
(0.575)\end{array}$ & $\begin{array}{l}2.182^{* *} \\
(0.713)\end{array}$ & $\begin{array}{l}2.226^{* *} \\
(0.730)\end{array}$ & $\begin{array}{l}2.292 * * \\
(0.744)\end{array}$ \\
\hline Republican & $\begin{array}{c}2.418^{* * *} \\
(0.570)\end{array}$ & $\begin{array}{l}1.861 * * \\
(0.517)\end{array}$ & $\begin{array}{c}2.421^{* * *} \\
(0.569)\end{array}$ & $\begin{array}{c}2.407 * * * \\
(0.575)\end{array}$ & $\begin{array}{c}2.431 * * * \\
(0.576)\end{array}$ & $\begin{array}{l}1.840^{* *} \\
(0.515)\end{array}$ & $\begin{array}{l}1.863 * * \\
(0.523)\end{array}$ & $\begin{array}{l}1.869 * * \\
(0.534)\end{array}$ \\
\hline Constant & $\begin{array}{c}0.444 \\
(0.352)\end{array}$ & $\begin{array}{c}0.360 \\
(0.298) \\
\end{array}$ & $\begin{array}{c}0.450 \\
(0.380) \\
\end{array}$ & $\begin{array}{c}2.513 \\
(2.678) \\
\end{array}$ & $\begin{array}{c}1.655 \\
(2.009) \\
\end{array}$ & $\begin{array}{c}0.228 \\
(0.221) \\
\end{array}$ & $\begin{array}{c}0.360 \\
(0.370)\end{array}$ & $\begin{array}{c}2.332 \\
(2.820)\end{array}$ \\
\hline Observations & 512 & 361 & 512 & 512 & 512 & 361 & 361 & 361 \\
\hline MSAs & 91 & 89 & 91 & 91 & 91 & 89 & 89 & 89 \\
\hline Log likelihood & -324.1 & -224.3 & -324.1 & -321.7 & -323.7 & -223.6 & -223.1 & -220.0 \\
\hline
\end{tabular}


Table 2: Exposure to Race or Poverty and Opposition to Welfare

\begin{tabular}{|c|c|c|c|c|}
\hline \multirow[b]{2}{*}{ Opposition to Welfare } & (1) & (2) & (3) & (4) \\
\hline & \multicolumn{2}{|c|}{ Laziness Stereotype } & \multicolumn{2}{|c|}{ Symbolic Racism } \\
\hline \multicolumn{5}{|l|}{$\underline{\text { Racial Attitudes }}$} \\
\hline Laziness Stereotype & $\begin{array}{c}1.260 * * * \\
(0.097)\end{array}$ & $\begin{array}{c}1.036 \\
(0.120)\end{array}$ & & \\
\hline Symbolic Racism & & & $\begin{array}{l}1.227 * * * \\
(0.075)\end{array}$ & $\begin{array}{c}1.643 * * * \\
(0.252)\end{array}$ \\
\hline \multicolumn{5}{|l|}{ Contextual Variables } \\
\hline Poverty Rate & $\begin{array}{c}1.000 \\
(0.020)\end{array}$ & $\begin{array}{c}1.001 \\
(0.020)\end{array}$ & & \\
\hline Percent Black (log) & & & $\begin{array}{c}0.962 \\
(0.110)\end{array}$ & $\begin{array}{c}0.988 \\
(0.105)\end{array}$ \\
\hline Racial Segregation & $\begin{array}{l}1.004 \\
(0.012)\end{array}$ & $\begin{array}{l}0.864 * * \\
(0.052)\end{array}$ & & \\
\hline $\begin{array}{l}\text { Laziness Stereotype } \\
\times \text { Racial Segregation }\end{array}$ & & $\begin{array}{l}1.027 * * \\
(0.010)\end{array}$ & & \\
\hline Income Segregation & & & $\begin{array}{c}0.916 \\
(0.050)\end{array}$ & $\begin{array}{c}1.290 \\
(0.220)\end{array}$ \\
\hline $\begin{array}{l}\text { Symbolic Racism } \\
\times \text { Income Segregation }\end{array}$ & & & & $\begin{array}{l}0.945^{* *} \\
(0.024)\end{array}$ \\
\hline \multicolumn{5}{|l|}{ Control Variables } \\
\hline Age & $\begin{array}{c}0.992 \\
(0.006)\end{array}$ & $\begin{array}{c}0.992 \\
(0.006)\end{array}$ & $\begin{array}{c}0.993 \\
(0.007)\end{array}$ & $\begin{array}{c}0.994 \\
(0.007)\end{array}$ \\
\hline Gender & $\begin{array}{c}1.283 \\
(0.245)\end{array}$ & $\begin{array}{c}1.289 \\
(0.247)\end{array}$ & $\begin{array}{c}1.225 \\
(0.291)\end{array}$ & $\begin{array}{c}1.142 \\
(0.278)\end{array}$ \\
\hline Marital Status & $\begin{array}{l}1.133 \\
(0.219)\end{array}$ & $\begin{array}{c}1.131 \\
(0.217)\end{array}$ & $\begin{array}{c}1.070 \\
(0.258)\end{array}$ & $\begin{array}{c}1.071 \\
(0.266)\end{array}$ \\
\hline Education (years) & $\begin{array}{l}0.931 * * \\
(0.033)\end{array}$ & $\begin{array}{l}0.931 * * \\
(0.033)\end{array}$ & $\begin{array}{c}0.944 \\
(0.043)\end{array}$ & $\begin{array}{c}0.951 \\
(0.045)\end{array}$ \\
\hline Income & $\begin{array}{l}1.000 \\
(0.000)\end{array}$ & $\begin{array}{c}1.000 \\
(0.000)\end{array}$ & $\begin{array}{c}1.000 \\
(0.000)\end{array}$ & $\begin{array}{c}1.000 \\
(0.000)\end{array}$ \\
\hline Independent & $\begin{array}{c}2.113 * * * \\
(0.559)\end{array}$ & $\begin{array}{c}2.066^{* * * *} \\
(0.555)\end{array}$ & $\begin{array}{l}2.319 * * \\
(0.771)\end{array}$ & $\begin{array}{c}2.436 * * * \\
(0.814)\end{array}$ \\
\hline Republican & $\begin{array}{c}2.406^{* * * *} \\
(0.563)\end{array}$ & $\begin{array}{c}2.436 * * * \\
(0.581)\end{array}$ & $\begin{array}{l}1.899 * * \\
(0.530)\end{array}$ & $\begin{array}{l}1.926^{* *} \\
(0.549)\end{array}$ \\
\hline Constant & $\begin{array}{c}0.429 \\
(0.365)\end{array}$ & $\begin{array}{c}1.236 \\
(1.200)\end{array}$ & $\begin{array}{c}0.662 \\
(0.623)\end{array}$ & $\begin{array}{c}0.0942 * \\
(0.128)\end{array}$ \\
\hline Observations & 512 & 512 & 361 & 361 \\
\hline MSAs & 91 & 91 & 89 & 89 \\
\hline Log likelihood & -324.1 & -321.8 & -223.3 & -220.5 \\
\hline
\end{tabular}


Table 3: Racialized Welfare Preferences in Context: ANES Replication

\begin{tabular}{|c|c|c|c|c|}
\hline Opposition to Welfare & \multicolumn{2}{|c|}{ Laziness Stereotype } & \multicolumn{2}{|c|}{ Symbolic Racism } \\
\hline$\underline{\text { Racial Attitudes }}$ & & & & \\
\hline$\overline{\text { Laziness Stereotype }}$ & $\begin{array}{c}0.991 \\
(0.111)\end{array}$ & $\begin{array}{c}0.888 \\
(0.085)\end{array}$ & & \\
\hline Racial Resentment & & & $\begin{array}{c}1.069 \\
(0.059)\end{array}$ & $\begin{array}{c}1.212^{* * * *} \\
(0.069)\end{array}$ \\
\hline \multicolumn{5}{|l|}{ Contextual Variables } \\
\hline Percent Black (log) & $\begin{array}{c}0.619 \\
(0.217)\end{array}$ & & $\begin{array}{c}1.052 \\
(0.075)\end{array}$ & $\begin{array}{c}1.078 \\
(0.076)\end{array}$ \\
\hline Poverty Rate & $\begin{array}{l}1.004 \\
(0.015)\end{array}$ & $\begin{array}{c}1.008 \\
(0.014)\end{array}$ & $\begin{array}{c}0.959 \\
(0.034)\end{array}$ & \\
\hline $\begin{array}{l}\text { Laziness Stereotype } \\
\times \text { Percent Black }(\log )\end{array}$ & $\begin{array}{l}1.108^{*} \\
(0.066)\end{array}$ & & & \\
\hline Racial Segregation & & $\begin{array}{c}0.819 * * * \\
(0.058)\end{array}$ & & \\
\hline $\begin{array}{l}\text { Laziness Stereotype } \\
\times \text { Racial Segregation }\end{array}$ & & $\begin{array}{l}1.040 * * * \\
(0.012)\end{array}$ & & \\
\hline $\begin{array}{l}\text { Racial Resentment } \\
\times \text { Poverty Rate }\end{array}$ & & & $\begin{array}{l}1.008^{*} \\
(0.005)\end{array}$ & \\
\hline Income Segregation & & & & $\begin{array}{c}1.462 \\
(1.010)\end{array}$ \\
\hline $\begin{array}{l}\text { Racial Resentment } \\
\times \text { Income Segregation }\end{array}$ & & & & $\begin{array}{c}0.934 \\
(0.084)\end{array}$ \\
\hline \multicolumn{5}{|l|}{ Control Variables } \\
\hline Age & $\begin{array}{c}0.994 \\
(0.005)\end{array}$ & $\begin{array}{c}0.995 \\
(0.005)\end{array}$ & $\begin{array}{c}0.993 \\
(0.005)\end{array}$ & $\begin{array}{c}0.994 \\
(0.005)\end{array}$ \\
\hline Male & $\begin{array}{c}0.941 \\
(0.140)\end{array}$ & $\begin{array}{c}0.961 \\
(0.145)\end{array}$ & $\begin{array}{c}0.918 \\
(0.137)\end{array}$ & $\begin{array}{c}0.925 \\
(0.137)\end{array}$ \\
\hline Marital Status & $\begin{array}{c}1.053 \\
(0.167)\end{array}$ & $\begin{array}{c}1.059 \\
(0.170)\end{array}$ & $\begin{array}{c}1.052 \\
(0.169)\end{array}$ & $\begin{array}{c}1.060 \\
(0.171)\end{array}$ \\
\hline Education & $\begin{array}{c}0.949 \\
(0.047)\end{array}$ & $\begin{array}{c}0.950 \\
(0.048)\end{array}$ & $\begin{array}{c}1.006 \\
(0.051)\end{array}$ & $\begin{array}{c}1.008 \\
(0.051)\end{array}$ \\
\hline Income & $\begin{array}{l}1.044^{*} \\
(0.025)\end{array}$ & $\begin{array}{l}1.046^{*} \\
(0.026)\end{array}$ & $\begin{array}{c}1.034 \\
(0.027)\end{array}$ & $\begin{array}{c}1.030 \\
(0.026)\end{array}$ \\
\hline Independent & $\begin{array}{c}1.270 \\
(0.267)\end{array}$ & $\begin{array}{c}1.207 \\
(0.255)\end{array}$ & $\begin{array}{c}1.152 \\
(0.243)\end{array}$ & $\begin{array}{c}1.120 \\
(0.237)\end{array}$ \\
\hline Republican & $\begin{array}{c}1.777 * * * \\
(0.276)\end{array}$ & $\begin{array}{c}1.728 * * * \\
(0.275)\end{array}$ & $\begin{array}{c}1.578 * * * \\
(0.251)\end{array}$ & $\begin{array}{c}1.549 * * * \\
(0.248)\end{array}$ \\
\hline Constant & $\begin{array}{c}0.558 \\
(0.433) \\
\end{array}$ & $\begin{array}{c}0.956 \\
(0.679) \\
\end{array}$ & $\begin{array}{c}0.290 * * \\
(0.167) \\
\end{array}$ & $\begin{array}{c}0.140 * * * \\
(0.083) \\
\end{array}$ \\
\hline Observations & 858 & 852 & 872 & 867 \\
\hline Congressional Districts & 290 & 291 & 288 & 290 \\
\hline Log likelihood & -556.2 & -548.8 & -551.8 & -549.4 \\
\hline \multicolumn{5}{|c|}{$\begin{array}{l}\text { Table reports odds ratios from logistic regression estimating } \\
\text { probability of saying too much is spent on welfare; standard errors in } \\
\text { parentheses. } \\
\text { Source: } 2000 \text { American National Election Study. } \\
\text { Party base category is Democrat. } \\
* \mathrm{p}<0.10, * * \mathrm{p}<0.05, * * * \mathrm{p}<0.01\end{array}$} \\
\hline
\end{tabular}


Figures

Figure 1: Correlation between Racial Attitude Variables

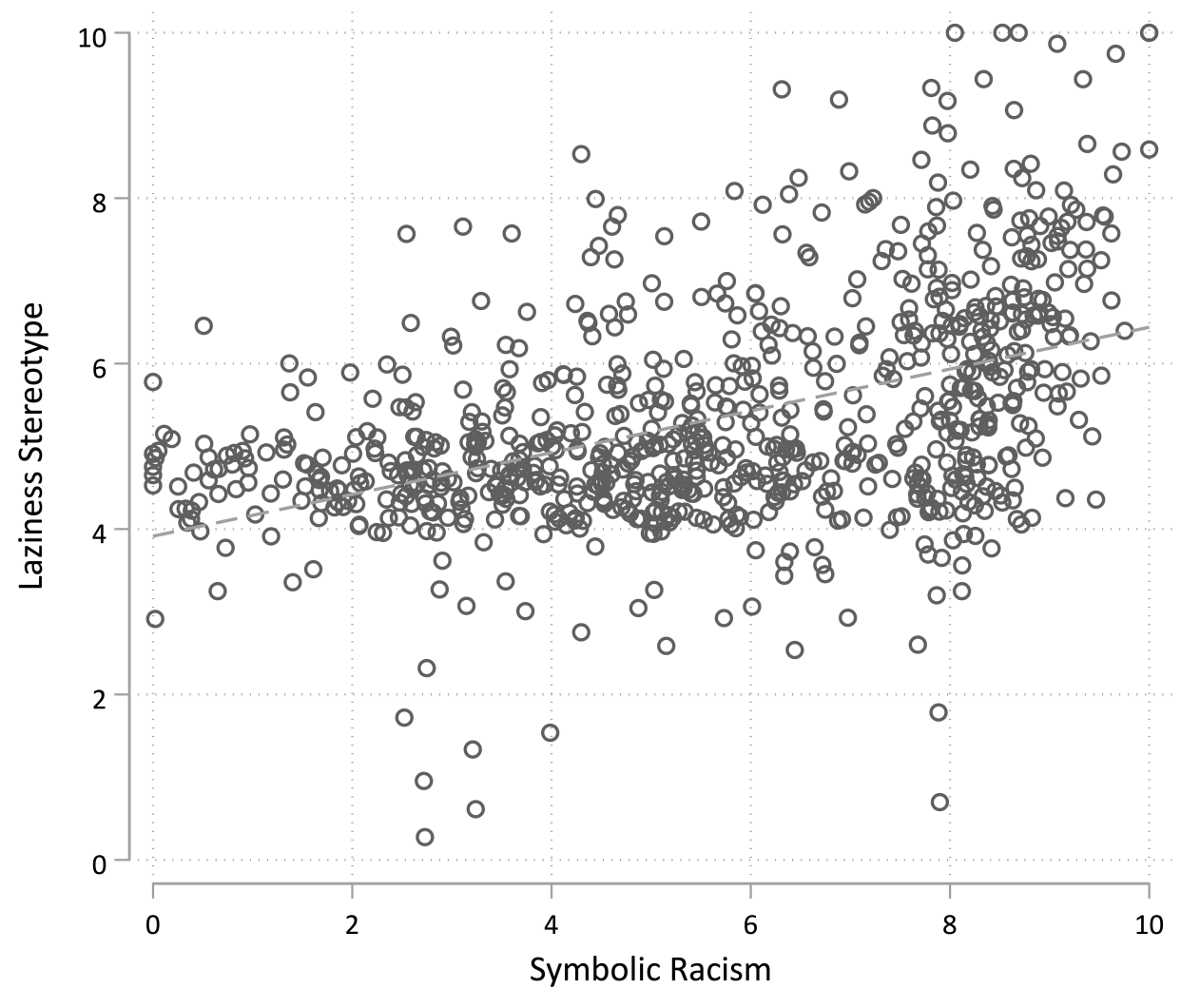

Source: 2000 General Social Survey $(n=1,224)$. Figure visualizes where whites in GSS sample rank on measures of both traditional prejudice and symbolic racism. 
Figure 2: Black Population Presence and Poverty Rates by Metropolitan Area, 2000
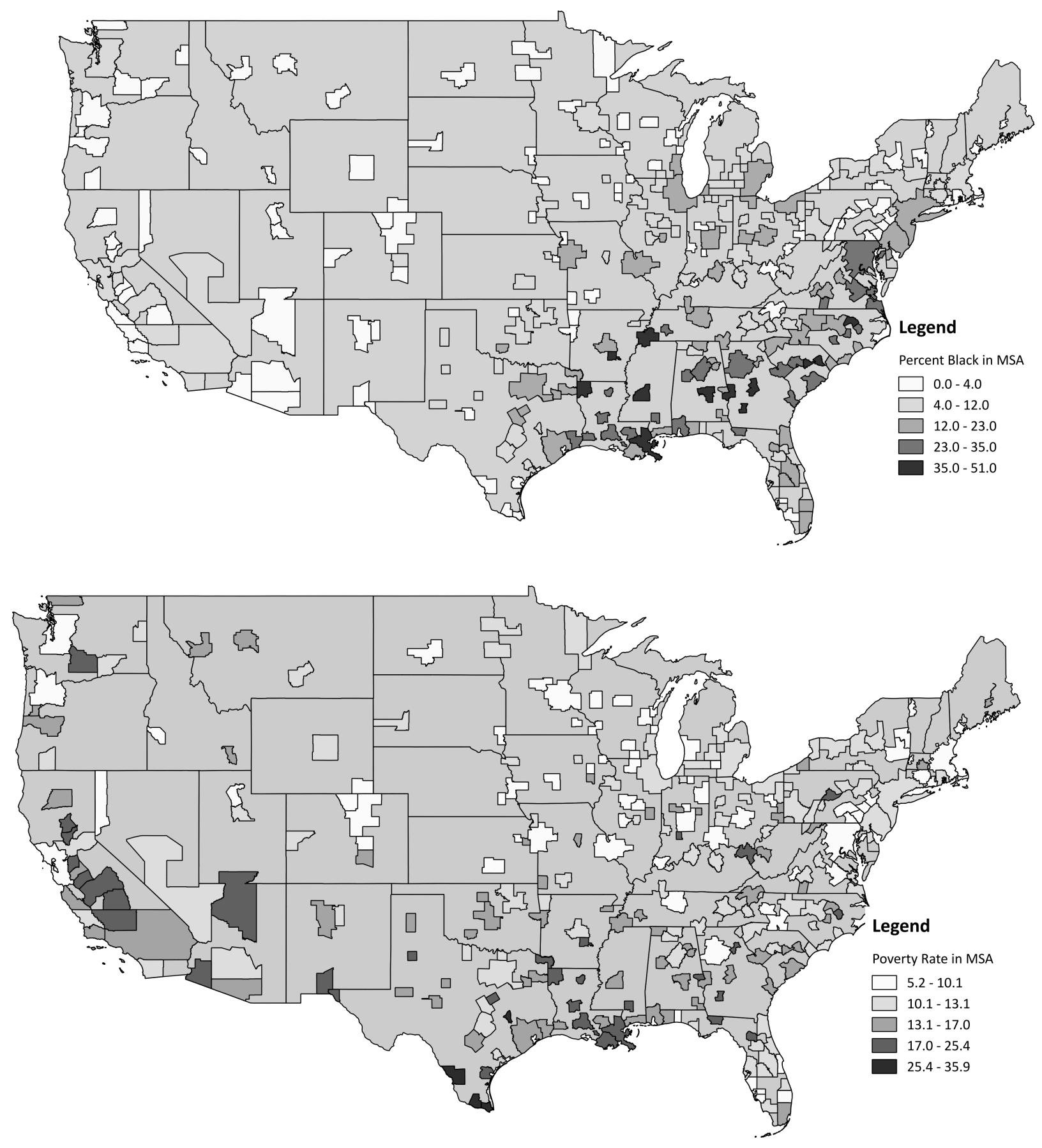

Maps use TIGER/Line Shapefiles and census data to illustrate black population share and poverty rates across MSAs as of 2000. 
Figure 3: The Polarization of Welfare Preferences by Racial Attitudes

(a) Effect of Black Population Share on White Welfare Preferences

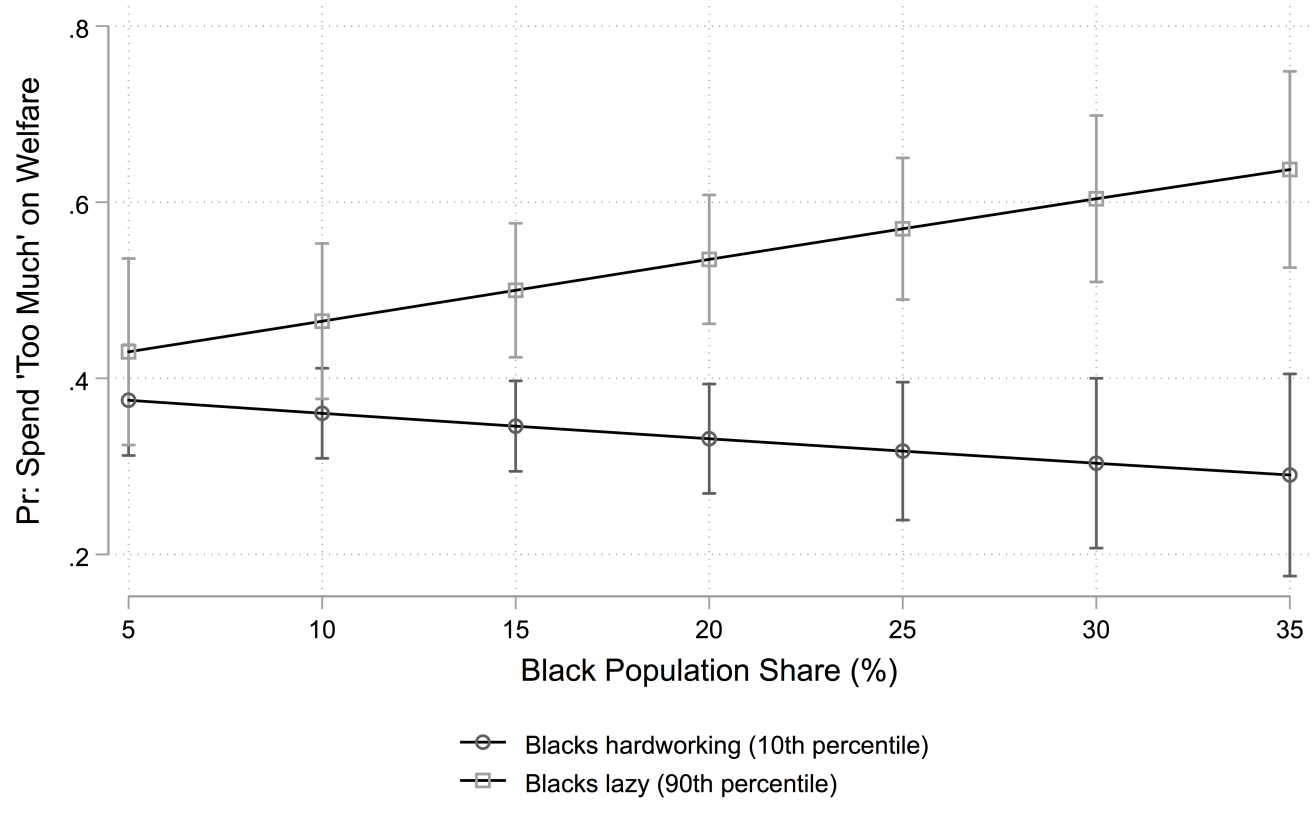

(b) Effect of Poverty Rate on White Welfare Preferences

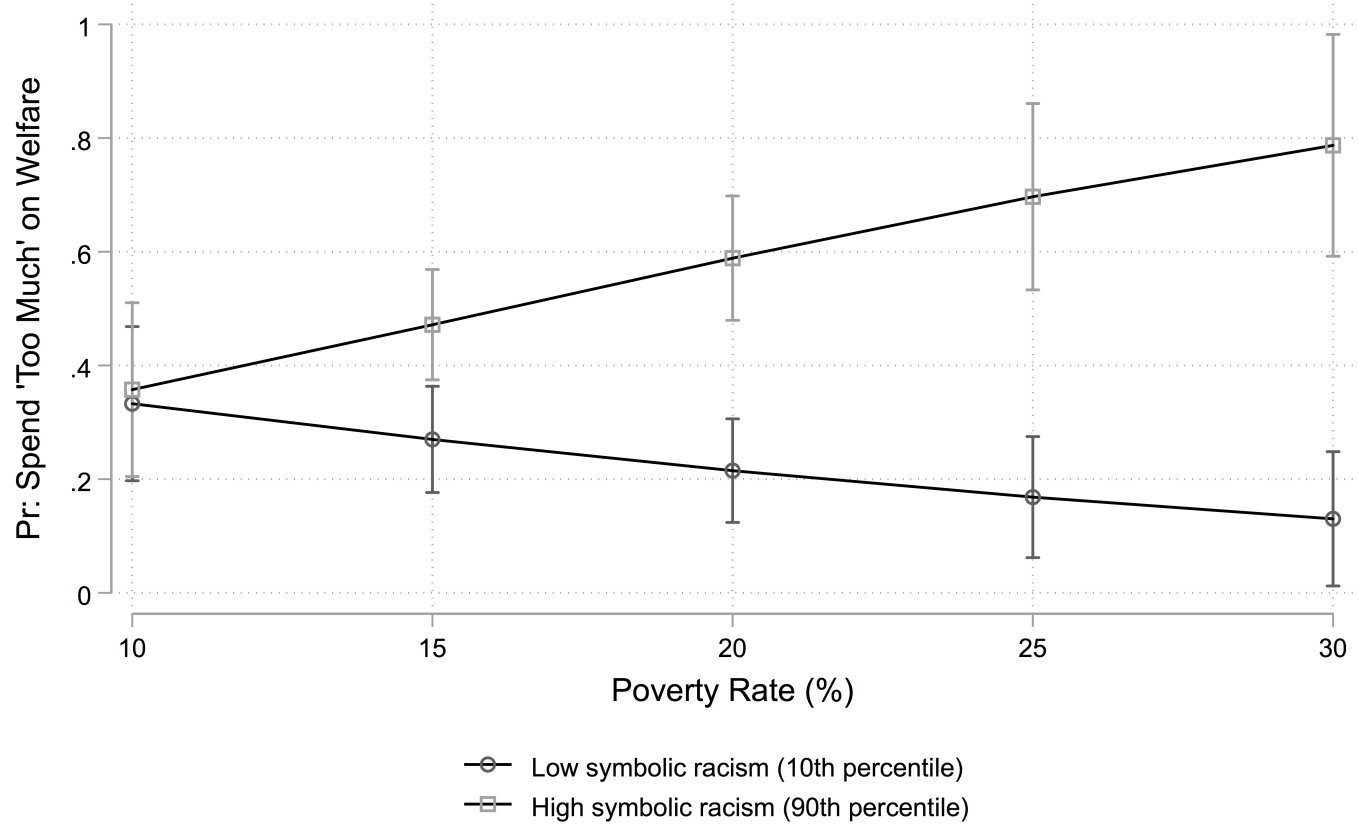

Source: 2000 General Social Survey. Top graph visualizes the interaction posed in Model 4 in Table 1. Bottom graph visualizes the interaction posed in Model 8 in Table 1. 
Figure 4: Segregation and the Visibility of Black or Poor Populations

(a) Effect of Racial Segregation on White Welfare Preferences

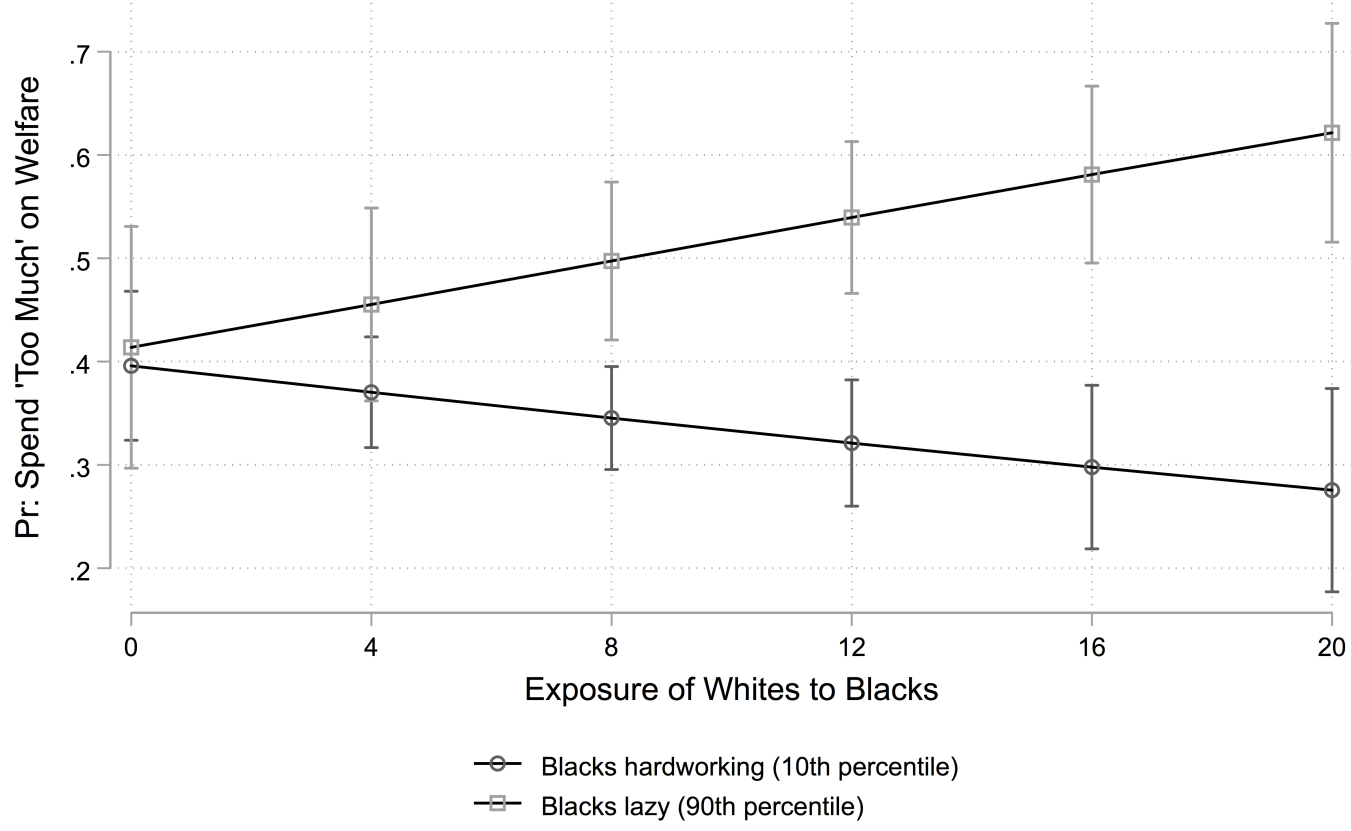

(b) Effect of Income Segregation on White Welfare Preferences

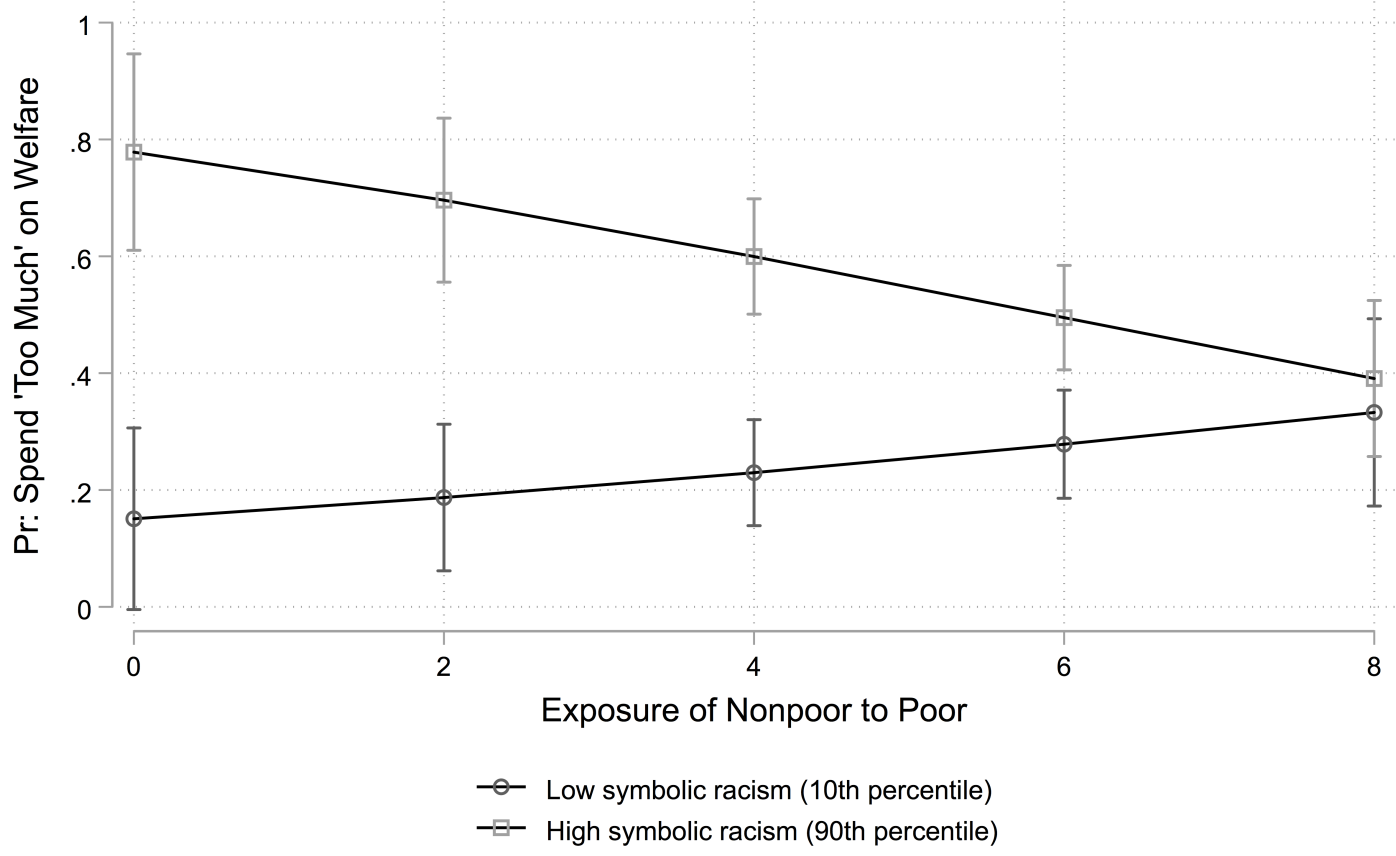

Source: 2000 General Social Survey. Top graph visualizes the interaction posed in Model 2 in Table 2. Bottom graph visualizes the interaction posed in Model 4 in Table 2. 


\section{Appendices}

(Supplemental information intended for online publication)

\section{Extracting a symbolic racism factor}

Table A1 reports the results of the factor analysis I conduct to construct a symbolic racism factor, following Tarman and Sears (2005). These authors conduct factor analysis on five GSS surveys administered between 1994 and 2000 in order to demonstrate consistency in the conceptual distinction between old-fashioned and symbolic racism over time. My only departure from Tarman and Sears is my decision not to include a question about whether interracial marriage should be legal. By the time of the 2000 survey, this question is answered by so few that I eliminate it in order to avoid limiting my symbolic racism scale to a small number of survey responses.

Note that I keep the symbolic racism (SR) factor produced by the factor analysis but discard the old-fashioned racism (OFR) factor. I instead focus on the black laziness stereotype as a measure of traditional prejudice, given the centrality of this particular belief in explaining opposition to welfare.

[Table A1 about here]

\section{County-level predictors of welfare preferences}

In this appendix, I report the results of analysis conducted using county-level measures of black population share and poverty rate in order to ensure that my results are not purely the product of how MSA boundaries are drawn. I have explained my focus on the MSA (or metropolitan division when applicable; see note 4) on the grounds that urban residents are likely to cross county lines in their daily activities and also to be aware of populations in neighboring counties. However, counties (as opposed to states or census tracts) are similar to MSAs as mid- 
size containers, and therefore county-level data should produce similar results when incorporated into the analysis.

Table A2 presents the results of this analysis. The interactions between both measures of racial geography (either black population share or racial segregation) and the laziness stereotype hold when measuring context at the county level. The interaction between income segregation and symbolic racism also remains significant. The interaction between symbolic racism and county poverty rate, however, is no longer significant $(\mathrm{p}=0.107)$. This result is consistent with the reasoning behind my incorporation of central city poverty rates in the main analysis. It is possible that sorting within a metropolitan area produces variation in poverty rates among the counties that comprise an MSA. Despite this sorting, we would expect metropolitan area residents to have a general awareness of visible, central city poverty.

[Table A2 about here]

\section{"Assistance to the poor" versus "welfare"}

I conduct a confirmatory test of my main results by repeating the analysis using the dependent variable "assistance to the poor," which lacks welfare's reputation as a threat to the way of life of hardworking Americans. The relative unpopularity of welfare is apparent in the GSS dataset: $39.45 \%$ of the sample says too much is spent on welfare, compared to $13.48 \%$ among those respondents who were instead asked about assistance to the poor.

Still, both racial attitude variables are predictive of opinion regarding assistance to the poor in the first two models of Table A3. In other words, attitudes about blacks are implicated even when a less racialized term is used.

[Table A3 about here] 
However, neither previously identified interaction between racial attitudes and context holds when assistance to the poor is the dependent variable. Racial geography does not make traditional racial prejudice more accessible in regard to a race-neutral reference to redistribution; economic geography is similarly insignificant in determining the effect of symbolic racism on views about assistance to the poor. In a similar vein, party identification was a significant predictor of welfare views - reflecting the Republican Party's embrace of the narrative that welfare encourages dependency - but is not significant in predicting views on assisting the poor. The results reported in this appendix therefore indicate the power of a policy narrative to make particular racial attitudes sensitive to contextual symbols associated with welfare.

Note that the slight significance of black population share in the fourth column of Table A3 and the simultaneous insignificance of symbolic racism in that model may be a product of the small effect of black population share in predicting higher levels of symbolic racism, discussed in the next appendix.

\section{The possible endogeneity of attitudes to context}

Some applications of the threat hypothesis have argued that a greater minority presence will increase the expression of prejudice among majority group members, posing prejudice itself rather than vote choice or policy preferences as the dependent variable (e.g. Quillian 1995). My analysis instead assumes that racial attitudes are exogenous to the settings in which people live. This assumption is inevitably imperfect, but with policy preferences as the outcome variable, it would be futile to investigate any predictive power of context without controlling for white individuals' orientations toward blacks (see Branton and Jones 2005 for a similar approach).

Furthermore, I confirm that the effects of context on racial animus itself are minimal in the 2000 GSS sample, evidenced by OLS regression clustering standard errors by MSA (Table A4). Poverty rate is not significant in predicting either racial attitude variable. Black population share is not significant in predicting agreement with the black laziness stereotype, although it is 
predictive of symbolic racism. A unit increase in percent black predicts an increase of 0.03 on the 0-10 symbolic racism scale $(\mathrm{p}<0.01)$. However, I deem this effect small enough not to bias my results when controlling for context and racial attitudes together. Moreover, even if levels of symbolic racism are slightly higher in racially diverse contexts, the fact that economic geography (i.e. poverty rate) rather than racial geography is predicted to amplify the effect of symbolic racism dampens concerns about endogeneity in the symbolic racism models.

[Table A4 about here]

In a separate analysis, I confirm that the welfare preferences I study at the MSA level do not simply reflect differences across states or regions. Table A5 presents two approaches to accounting for regional and state-level characteristics that are shared across MSAs. The first two models include a dummy variable for the region in which each MSA is located, and the second uses multilevel modeling to nest each MSA within a state. Across the models, the interaction between attitudes and contexts remains significant. Orientations toward blacks as well as ideas about welfare spending may partially reflect cultural differences across the United States - but, after accounting for these, I still find that features of local context are predictive of the strength of the relationship between racial attitudes and welfare preferences.

[Table A5 about here] 


\section{Appendix Tables}

Table A1: Racial Attitude Factor Loadings

SR Factor

OFR Factor

Symbolic racism (SR)

Discrimination not responsible for racial disparities

0.49

$-0.13$

Lack of motivation is responsible for disparities

0.47

0.26

Blacks should work their way up; no special favors

0.51

0.10

Old-fashioned racism (OFR)

Lack of inborn ability is responsible for disparities

0.02

0.48

Blacks lack intelligence (compared to whites)

0.11

0.44

Interfactor correlation $=0.36$

Source: 2000 General Social Survey $(n=2,213)$. Table reports coefficients from exploratory factor analysis, oblique rotations, including all non-black respondents. Factor loadings exceeding 0.40 are bolded. 
Table A2: Racialized Welfare Preferences Across Counties

\begin{tabular}{|c|c|c|c|c|c|c|}
\hline \multirow[b]{2}{*}{ Opposition to Welfare } & (1) & (2) & (3) & (4) & (5) & (6) \\
\hline & \multicolumn{3}{|c|}{ Laziness Stereotype } & \multicolumn{3}{|c|}{ Symbolic Racism } \\
\hline \multicolumn{7}{|l|}{$\underline{\text { Racial Attitudes }}$} \\
\hline$\overline{\text { Laziness Stereotype }}$ & $\begin{array}{l}1.257^{* * * *} \\
(0.101)\end{array}$ & $\begin{array}{c}0.961 \\
(0.139)\end{array}$ & $\begin{array}{c}1.043 \\
(0.125)\end{array}$ & & & \\
\hline Symbolic Racism & & & & $\begin{array}{l}1.219^{* * * *} \\
(0.066)\end{array}$ & $\begin{array}{c}0.977 \\
(0.141)\end{array}$ & $\begin{array}{l}1.652^{* * * *} \\
(0.234)\end{array}$ \\
\hline \multicolumn{7}{|l|}{ Contextual Variables } \\
\hline $\begin{array}{l}\overline{\text { County Percent Black }} \\
(\log )\end{array}$ & $\begin{array}{l}1.005 \\
(0.084)\end{array}$ & $\begin{array}{l}0.503^{* *} \\
(0.150)\end{array}$ & & $\begin{array}{c}1.066 \\
(0.112)\end{array}$ & $\begin{array}{c}1.052 \\
(0.112)\end{array}$ & $\begin{array}{c}1.081 \\
(0.111)\end{array}$ \\
\hline County Poverty Rate & $\begin{array}{c}1.028 \\
(0.023)\end{array}$ & $\begin{array}{c}1.024 \\
(0.023)\end{array}$ & $\begin{array}{c}1.026 \\
(0.021)\end{array}$ & $\begin{array}{c}1.024 \\
(0.030)\end{array}$ & $\begin{array}{c}0.906 \\
(0.072)\end{array}$ & \\
\hline $\begin{array}{l}\text { Laziness Stereotype } \\
\times \text { County Percent Black }(\log )\end{array}$ & & $\begin{array}{l}1.140^{* *} \\
(0.065)\end{array}$ & & & & \\
\hline Racial Segregation & & & $\begin{array}{l}0.866^{* *} \\
(0.051)\end{array}$ & & & \\
\hline $\begin{array}{l}\text { Laziness Stereotype } \\
\times \text { Racial Segregation }\end{array}$ & & & $\begin{array}{l}1.025^{* *} \\
(0.011)\end{array}$ & & & \\
\hline $\begin{array}{l}\text { Symbolic Racism } \\
\times \text { County Poverty Rate }\end{array}$ & & & & & $\begin{array}{c}1.021 \\
(0.013)\end{array}$ & \\
\hline Income Segregation & & & & & & $\begin{array}{l}1.339^{*} \\
(0.207)\end{array}$ \\
\hline $\begin{array}{l}\text { Symbolic Racism } \\
\times \text { Income Segregation }\end{array}$ & & & & & & $\begin{array}{r}0.943^{* *} \\
(0.022)\end{array}$ \\
\hline \multicolumn{7}{|l|}{ Control Variables } \\
\hline Age & $\begin{array}{c}0.992 \\
(0.006)\end{array}$ & $\begin{array}{c}0.992 \\
(0.006)\end{array}$ & $\begin{array}{c}0.992 \\
(0.006)\end{array}$ & $\begin{array}{c}0.993 \\
(0.007)\end{array}$ & $\begin{array}{c}0.991 \\
(0.007)\end{array}$ & $\begin{array}{c}0.994 \\
(0.007)\end{array}$ \\
\hline Gender & $\begin{array}{c}1.283 \\
(0.248)\end{array}$ & $\begin{array}{c}1.299 \\
(0.252)\end{array}$ & $\begin{array}{c}1.287 \\
(0.245)\end{array}$ & $\begin{array}{c}1.249 \\
(0.291)\end{array}$ & $\begin{array}{c}1.212 \\
(0.284)\end{array}$ & $\begin{array}{c}1.161 \\
(0.274)\end{array}$ \\
\hline Marital Status & $\begin{array}{c}1.138 \\
(0.221)\end{array}$ & $\begin{array}{c}1.142 \\
(0.221)\end{array}$ & $\begin{array}{c}1.134 \\
(0.215)\end{array}$ & $\begin{array}{c}1.105 \\
(0.261)\end{array}$ & $\begin{array}{c}1.109 \\
(0.269)\end{array}$ & $\begin{array}{c}1.102 \\
(0.270)\end{array}$ \\
\hline Education (years) & $\begin{array}{l}0.930^{* *} \\
(0.034)\end{array}$ & $\begin{array}{l}0.932 * * \\
(0.033)\end{array}$ & $\begin{array}{l}0.930 * * \\
(0.034)\end{array}$ & $\begin{array}{c}0.953 \\
(0.043)\end{array}$ & $\begin{array}{c}0.953 \\
(0.045)\end{array}$ & $\begin{array}{c}0.952 \\
(0.044)\end{array}$ \\
\hline Income & $\begin{array}{c}1.000 \\
(0.000)\end{array}$ & $\begin{array}{c}1.000 \\
(0.000)\end{array}$ & $\begin{array}{c}1.000 \\
(0.000)\end{array}$ & $\begin{array}{c}1.000 \\
(0.000)\end{array}$ & $\begin{array}{c}1.000 \\
(0.000)\end{array}$ & $\begin{array}{c}1.000 \\
(0.000)\end{array}$ \\
\hline Independent & $\begin{array}{l}2.158 * * * \\
(0.559)\end{array}$ & $\begin{array}{l}2.125 * * * \\
(0.559)\end{array}$ & $\begin{array}{l}2.116^{* * *} \\
(0.553)\end{array}$ & $\begin{array}{l}2.255^{* * * *} \\
(0.688)\end{array}$ & $\begin{array}{c}2.146 * * \\
(0.644)\end{array}$ & $\begin{array}{c}2.411 * * * \\
(0.743)\end{array}$ \\
\hline Republican & $\begin{array}{l}2.379 * * * \\
(0.530)\end{array}$ & $\begin{array}{l}2.335 * * * \\
(0.520)\end{array}$ & $\begin{array}{l}2.420 * * * \\
(0.541)\end{array}$ & $\begin{array}{l}1.821^{* *} \\
(0.491)\end{array}$ & $\begin{array}{c}1.810^{* *} \\
(0.488)\end{array}$ & $\begin{array}{l}1.907 * * \\
(0.526)\end{array}$ \\
\hline Constant & $\begin{array}{c}0.324 \\
(0.270) \\
\end{array}$ & $\begin{array}{c}1.298 \\
(1.287) \\
\end{array}$ & $\begin{array}{c}0.940 \\
(0.875) \\
\end{array}$ & $\begin{array}{c}0.234 \\
(0.209) \\
\end{array}$ & $\begin{array}{c}0.985 \\
(1.215) \\
\end{array}$ & $\begin{array}{c}0.0644^{* *} \\
(0.084) \\
\end{array}$ \\
\hline Observations & 512 & 512 & 512 & 361 & 361 & 361 \\
\hline Counties & 147 & 147 & 147 & 136 & 136 & 136 \\
\hline Log likelihood & -323.3 & -321.0 & -321.2 & -223.5 & -222.1 & -220.2 \\
\hline
\end{tabular}


Table A3: No Effect of Context on Opposition to Assisting the Poor

\begin{tabular}{|c|c|c|c|c|}
\hline \multirow[b]{2}{*}{ Assisting the Poor } & (1) & (2) & (3) & (4) \\
\hline & \multicolumn{2}{|c|}{ Laziness Stereotype } & \multicolumn{2}{|c|}{ Symbolic Racism } \\
\hline \multicolumn{5}{|l|}{ Racial Attitudes } \\
\hline Laziness Stereotype & $\begin{array}{l}1.418^{* * *} \\
(0.170)\end{array}$ & $\begin{array}{l}1.839^{* * *} \\
(0.379)\end{array}$ & & \\
\hline Symbolic Racism & & & $\begin{array}{l}1.171^{* *} \\
(0.077)\end{array}$ & $\begin{array}{l}1.238 \\
(0.200)\end{array}$ \\
\hline \multicolumn{5}{|l|}{ Contextual Variables } \\
\hline Percent Black (Log) & & $\begin{array}{c}1.763 \\
(0.944)\end{array}$ & & $\begin{array}{l}0.795^{*} \\
(0.097)\end{array}$ \\
\hline Poverty Rate & & $\begin{array}{c}1.005 \\
(0.025)\end{array}$ & & $\begin{array}{c}1.037 \\
(0.067)\end{array}$ \\
\hline $\begin{array}{l}\text { Laziness Stereotype } \\
\times \text { Percent Black (Log) }\end{array}$ & & $\begin{array}{c}0.883 \\
(0.078)\end{array}$ & & \\
\hline $\begin{array}{l}\text { Symbolic Racism } \\
\times \text { Poverty Rate }\end{array}$ & & & & $\begin{array}{c}0.997 \\
(0.009)\end{array}$ \\
\hline \multicolumn{5}{|l|}{ Control Variables } \\
\hline Independent & $\begin{array}{c}1.142 \\
(0.438)\end{array}$ & $\begin{array}{c}1.166 \\
(0.445)\end{array}$ & $\begin{array}{c}0.732 \\
(0.343)\end{array}$ & $\begin{array}{c}0.762 \\
(0.361)\end{array}$ \\
\hline Republican & $\begin{array}{c}1.518 \\
(0.486)\end{array}$ & $\begin{array}{c}1.570 \\
(0.506)\end{array}$ & $\begin{array}{c}1.359 \\
(0.484)\end{array}$ & $\begin{array}{c}1.377 \\
(0.509)\end{array}$ \\
\hline Age & $\begin{array}{c}0.998 \\
(0.007)\end{array}$ & $\begin{array}{c}0.998 \\
(0.007)\end{array}$ & $\begin{array}{c}0.993 \\
(0.009)\end{array}$ & $\begin{array}{c}0.994 \\
(0.009)\end{array}$ \\
\hline Gender & $\begin{array}{c}1.068 \\
(0.313)\end{array}$ & $\begin{array}{c}1.070 \\
(0.321)\end{array}$ & $\begin{array}{c}1.114 \\
(0.350)\end{array}$ & $\begin{array}{c}1.155 \\
(0.379)\end{array}$ \\
\hline Marital Status & $\begin{array}{l}1.036 \\
(0.275)\end{array}$ & $\begin{array}{c}1.103 \\
(0.294)\end{array}$ & $\begin{array}{c}0.786 \\
(0.256)\end{array}$ & $\begin{array}{c}0.776 \\
(0.254)\end{array}$ \\
\hline Education (years) & $\begin{array}{l}1.098^{*} \\
(0.055)\end{array}$ & $\begin{array}{c}1.085 \\
(0.056)\end{array}$ & $\begin{array}{c}1.071 \\
(0.059)\end{array}$ & $\begin{array}{c}1.062 \\
(0.061)\end{array}$ \\
\hline Income & $\begin{array}{c}1.000 \\
(0.000)\end{array}$ & $\begin{array}{c}1.000 \\
(0.000)\end{array}$ & $\begin{array}{c}1.000 \\
(0.000)\end{array}$ & $\begin{array}{c}1.000 \\
(0.000)\end{array}$ \\
\hline Constant & $\begin{array}{c}0.00680^{* * *} \\
(0.008)\end{array}$ & $\begin{array}{c}0.00212^{* * *} \\
(0.003)\end{array}$ & $\begin{array}{c}0.0360^{* * *} \\
(0.038) \\
\end{array}$ & $\begin{array}{c}0.0301^{* *} \\
(0.045) \\
\end{array}$ \\
\hline Observations & 505 & 505 & 347 & 347 \\
\hline MSAs & 92 & 92 & 87 & 87 \\
\hline Log likelihood & -200.5 & -199.1 & -146.0 & -144.6 \\
\hline
\end{tabular}


Table A4: Effect of Racial Context on Racial Attitudes

\begin{tabular}{|c|c|c|}
\hline & $\begin{array}{c}(1) \\
\text { Dep. Var.: } \\
\text { Laziness Stereotype } \\
\end{array}$ & $\begin{array}{c}(2) \\
\text { Dep. Var.: } \\
\text { Symbolic Racism }\end{array}$ \\
\hline Percent Black & $\begin{array}{c}0.00689 \\
(0.005)\end{array}$ & $\begin{array}{c}0.0286^{* * *} \\
(0.010)\end{array}$ \\
\hline Age & $\begin{array}{c}0.0125^{* * *} \\
(0.003)\end{array}$ & $\begin{array}{c}0.0142 * * \\
(0.005)\end{array}$ \\
\hline Gender & $\begin{array}{l}0.0948 \\
(0.083)\end{array}$ & $\begin{array}{l}0.356^{* *} \\
(0.145)\end{array}$ \\
\hline Marital Status & $\begin{array}{l}0.0328 \\
(0.090)\end{array}$ & $\begin{array}{c}0.165 \\
(0.195)\end{array}$ \\
\hline Education (years) & $\begin{array}{c}-0.0734 * * * \\
(0.020)\end{array}$ & $\begin{array}{c}-0.230^{* * *} \\
(0.038)\end{array}$ \\
\hline Income (thous.) & $\begin{array}{c}0.000107 \\
(0.001)\end{array}$ & $\begin{array}{c}-0.00323 \\
(0.002)\end{array}$ \\
\hline Independent & $\begin{array}{c}0.100 \\
(0.114)\end{array}$ & $\begin{array}{c}0.406^{*} \\
(0.238)\end{array}$ \\
\hline Republican & $\begin{array}{l}0.0876 \\
(0.095)\end{array}$ & $\begin{array}{l}1.077 * * * \\
(0.226)\end{array}$ \\
\hline Poverty Rate & $\begin{array}{l}0.0118 \\
(0.008)\end{array}$ & $\begin{array}{c}0.00355 \\
(0.022)\end{array}$ \\
\hline Constant & $\begin{array}{c}5.316 * * * \\
(0.328)\end{array}$ & $\begin{array}{c}7.193 * * * \\
(0.794)\end{array}$ \\
\hline Observations & 1051 & 728 \\
\hline MSAs & 95 & 93 \\
\hline R-sq. & 0.0678 & 0.151 \\
\hline
\end{tabular}


Table A5: Controlling for Regional and State-Level Characteristics

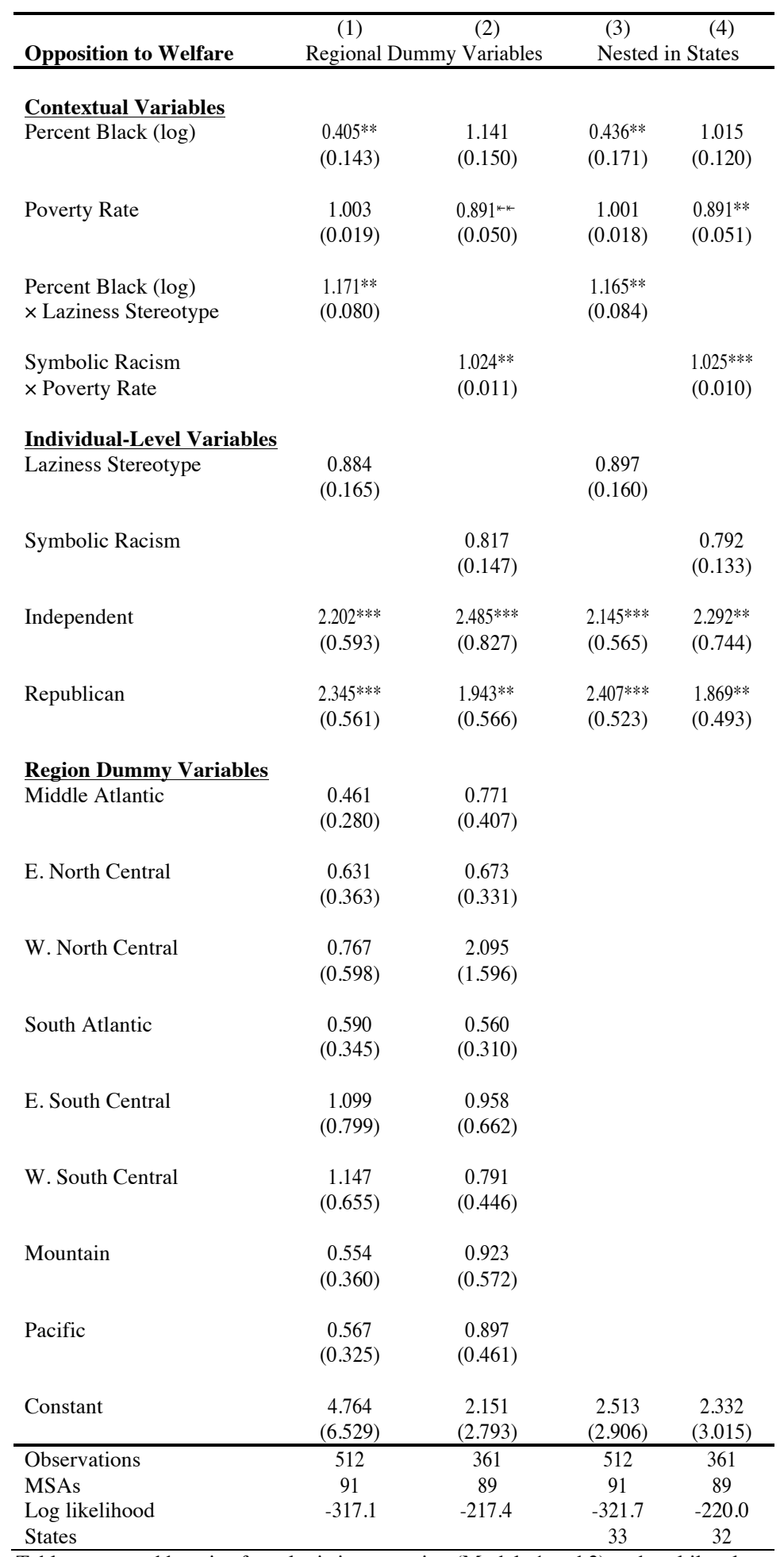

Table reports odds ratios from logistic regression (Models 1 and 2) and multilevel logistic regression (Models 3 and 4); standard errors in parentheses.

Party base category is Democrat; region base category is New England; for concision, other control variables are not displayed.

Source: 2000 General Social Survey.

$* \mathrm{p}<0.10, * * \mathrm{p}<0.05, * * * \mathrm{p}<0.01$ 